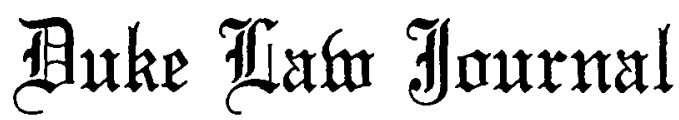

VOLUME 1980

SEPTEMBER

NUMBER 4

\section{OVERCOMING FUTURE SHOCK: ESTES REVISITED, OR A MODEST PROPOSAL FOR THE CONSTITUTIONAL PROTECTION OF THE NEWS-GATHERING PROCESS}

\section{DIANE L. ZIMMERMAN*}

"For the Constitution to have vitahity," wrote Chief Justice Earl Warren in 1965, "this Court must be able to apply its principles to situations that may not have been foreseen at the time those principles were adopted." 1 While the drafters of the sixth ainendinent to the Constitution were well grounded in the "experience of evils" 2 that could afflict a hapless defendant in a criminal case, they could not, Warren said, predict that the future would bring the invention of a totally new kind of evil: television. The Chief Justice therefore concurred in the judginent of four fellow Justices ${ }^{3}$ and made the adjustment he believed was demanded by subsequent history: lie declared that the trial court violated Billy Sol Estes's right to due process of law when it permitted television cameras in the courtroom. ${ }^{4}$

* Associate Professor of Law, New York University. A.B. 1963, Beaver College; J.D. 1976, Columbia University. Member, New York Bar.

The author wishes to thank the Honorable Jack B. Weinstein, United States District Court, Eastern District of New York, for his help and his insight. Thanks are due also to New York University law students Jillian Atwood and Paul Wilson, both of whom contributed very ably to the legal research. This Article was funded by grants from the New York University Law Center Foundation.

1. Estes v. Texas, 381 U.S. 532, 564 (1965) (Warren, C.J., concurring).

2. Id. (quoting Weems v. United States, 217 U.S. 349,373 (1910)). For a discussion of the "experience of evils" that the sixth amendment and other initial amendments were designed to prevent, see generally Black, The Bill of Rights, 35 N.Y.U. L. Rev. 865 (1960). in Estes.

3. Justices Clark, Warren, Douglas, Goldberg, and Harlan combined to form the majority

4. The broadcast coverage of Estes's trial was limited. Covered in full were pretrial motions by the defense for the exclusion of cameras and recording equipment and for a continuance. 381 U.S. at 535-36. During the trial, the court permitted camera crews to make live broadcasts of the 
The Supreme Court in Estes v. Texas concerned itself with preserving the core values of the sixth amendment against erosion in the face of radical change. Unfortunately, the principle enunciated by Chief Justice Warren was not applied as carefully to the other constitutional provision implicated in that decision: the first amendment. ${ }^{5}$ Change has similarly altered the world from the perspective of the free speech and press clauses, and the question left unanswered in Estes was how the core values of the first amendinent inight be adequately safeguarded when garbed in forms the founders could not have foreseen.

The Supreine Court in recent decades has intoned repeatedly that the first ainendment vigorously protects free speech and press in all its Protean modern guises. ${ }^{6}$ The actual holdings of its cases, however, suggest that in communications inedia, the printing press is first among equals. Legislators and government administrators have, with Court approval, exerted controls over the content and operations of the broadcast media that would be unthinkable if applied to the print media. ${ }^{7}$ The inajority in Estes, for example, suggested that the governinent may open a governmental event to reporters with notebooks but close it to the technological tools of radio and television. ${ }^{8}$ A series of contrasting cases after Estes reinforced this double standard. In Red Lion Broadcasting Co. v. FCC 9 the Supreine Court sanctioned major governmental intrusions into editorial control of the content of radio

state's opening and closing arguments, although mechanical difficulties blanked out the visual part of the broadcast of the opening, and of the return of the verdict. The court did not permit coverage of defense summations. During the trial, videotapes but no sound recordings were permitted. Id. at $537 \&$ n.2.

5. The first amendment provides: "Congress shall make no law . . . abridging the freedom of speech, or of the press . . . " U.S. CONST. amend. I.

6. See, e.g., Southeastern Promotions, Ltd. v. Conrad, 420 U.S. 546, $557-58$ (1975); Superior Films, Inc. v. Department of Educ., 346 U.S. 587 (1954); Joseph Burstyn, Inc. v. Wilson, 343 U.S. 495 (1952); United States v. Paramount Pictures, Inc., 334 U.S. 131, 166 (1948). Justice Douglas expressed the Court's overall attitude toward the diverse modes of modern communications in Superior Films, 346 U.S. at 589, as follows: "Motion pictures are of course a different medium of expression than the public speech, the radio, the stage, the novel, or the magazine. But the First Amendment draws no distinction between the various methods of communicating ideas."

7. The differences in the treatment of print versus broadcast media have occasioned much comment over the years. For a sampling of writings on one or more aspects of broadcast regulation which attempt to explore those differences, see, e.g., B. SCHMIDT, FreEdom OF THE PRESS v. Public Access (1976); Bollinger, Freedom of the Press and Public Access: Toward a Theory of Partial Regulation of the Mass Media, 75 Mich. L. REv. 1 (1976); Kalven, Broadcasting, Public Policy and the First Amendment, 10 J. LAw \& EcoN. 15 (1967); Robinson, The FCC and the First Amendment: Observations on 40 years of Radio and Television Regulation, 52 MINN. L. REV. 67 (1967).

8. 381 U.S. 532 (1965).

9. 385 U.S. 367 (1969). But cf. CBS, Inc. v. Democratic Nat'l Comm., 412 U.S. 94 (1973) (refusing to extend the fairness doctrine, see note 11 infra, to commercial advertising on matters of public interest). 
and television programming. The Court upheld a federal law mandating equal time for political candidates ${ }^{10}$ and approved the Federal Communications Commission's fairness doctrine ${ }^{11}$ and limited right of public access to privately held broadcast facilities to reply to personal attacks. ${ }^{12}$ When a similar riglit of reply theory was pursued against a newspaper in Miami Herald Publishing Co. v. Tornillo, ${ }^{13}$ however, the Court rejected the claim. More recently, in a case involving the radio broadcast of George Carlin's "Filthy Words" monologue, FCC v. Pacifica Foundation, ${ }^{14}$ the Court approved Federal Communications Commission regulation of speech deemed to be "indecent." The print media, as well as other "older" forms of expression such as motion pictures and live theater, enjoy a broader freedoin to be indecent; they are held to the less restrictive limit on free speech marked out by the obscenity standard..$^{15}$

These sorts of contrasts suggest that first amendment law has begun to diverge: restraints that cannot be imposed on the print media can be imposed on the electronic media. This development holds significance for the future of first amendment freedoms. The strict standards of noninterference that first amendment scholars have assuined

10. 47 U.S.C. $\S 315$ (1976).

11. The fairness doctrine is a policy developed by the Federal Communications Commission (FCC) requiring that broadcasters adequately cover public issues, and that in doing so they provide for the expression of opposing views. See generally Red Lion Broadcasting Co. v. FCC, 395 U.S. 367, 375-80 (1969).

12. The right of public access involved in Red Lion is set out in 47 C.F.R. $\$ \S 73.123,-.300$, $-.598,-.679(1979)$. The regulations provide that individuals against whom personal attacks are made on the air have a right to use the broadcaster's facilities to respond.

13. 418 U.S. 241 (1974).

14. 438 U.S. 726 (1978) (holding 18 U.S.C. $\$ 1464$ (1976), which prohibits the broadcasting of "obscene, indecent, or profane language," constitutional as apphed to the particular circumstances of the case).

15. See, e.g., Miller v. Cahfornia, 413 U.S. 15 (1973); Memoirs v. Massachusetts, 383 U.S. 413 (1966); Roth v. United States, 354 U.S. 476 (1957). But ff. Young v. American Mini Theatres, Inc., 427 U.S. 50 (1976) (a community may regulate the exhibition of nonobscene adult books and films by the use of zoning ordinances). The propriety of substantial government regulation of cable television, the newest mass medium, remains unsettled; the attempts to fit cable within the regulatory and first amendment framework currently governing broadcasters are unlikely to abate. The FCC first asserted jurisdiction over cable television in 1965. First Report and Order, 1 FCC 2d 453 (1965). Since then, the FCC has supported expansion of 18 U.S.C. \$ 1464-the criminal statute which prohibits utterance of "obscene, indecent, or profane language" in broadcasting-to include cable. Note, FCC Regulations of Cable Television Content, 31 RuTGERs L. Rev. 238 (1978). The Commission also promulgated regulations requiring larger cable system operators to set aside channels and facilities for programing by members of the public, the government, and educators. The Supreme Court invalidated those rules as exceeding the FCC's statutory authority in FCC v. Midwest Video Corp., 440 U.S. 689 (1979). Nevertheless, states and localities coutinue to impose access requirements on cable operators under the terms of their franchise agreements. See M. Hamburg, All. About Cable 519-24, 551-53 (1979); B. Schmidt, supra note 7 , at $199-216$. 
as the basis of a free press could ultimately decrease in importance by remaining linked to the printing press, a form of cominunication that inay well in a few short decades become obsolete. ${ }^{16}$

Yet the divergence of first amendment law into stronger protection for print media and more inodest protection for electronic media seems alınost inadvertent. The eourts, the Federal Communications Co1nmission, and others, in atteinpting to cope with new teclinology and with the astomishing growth in mass communications, have fixed their attention on the differences between the printed word and the product of cameras, recording devices, and broadcast equipment; they have failed, however, to perceive the constitutional common ground that these media share with the printed word. The developinent of law for the new teclinologies stems from an attempt to deal with the psychological impact of rapid change-Tofflerian future shock ${ }^{17}$-rather than a dispassionate attempt to elaborate a first amendment theory that accommodates "situations that may not have been foreseen at the time those principles were adopted." 18

Perhaps this is the right time, historically, to reexanme the development of the law and to reconcile the first amendment with the technology of modern communications. Though the unfamiliarity of television has worn off, communications experts believe we are on the verge of another revolution in the way we encode and dissenninate information. ${ }^{19}$ This combination of familiarity and unfamiliarity may provide both the objectivity and the impetus necessary for a closer examination of the justification for a two-tier system of first ainendment law.

This Article will consider one small segment of the larger task of rethinking the application of the first amendment to the multiple voices of the cominumications media. The broader subject is the extent of first amendinent protection for the reporter's choice of news-gathering technology. The immediate focus is the longstanding taboo against the use of caineras, tape recorders, and television broadcasting equipment in federal and state courts where reporters are nornally welcome to bring their notebooks. ${ }^{20}$

16. For descriptions of how various writers expect communications technology to develop in the future, including speculation on the reduced importance of print, see J. SERVAN-ScHRElBer, The Power to INFORM 178-88 (1974); Brown, Cable and Pay T.V. on Eve of Technological Revolution, N.Y. Times, July 31, 1978, \& C, at 12, col. 1; Walton, Do You Love Your VDT?, COLum. Journalism Rev., July-Aug. 1979, at 36.

17. See A. TOFFLER, Future SHOCK (1970).

18. Estes v. Texas, 381 U.S. at 564 (Warren, C.J., concurring).

19. See note 16 supra.

20. Reporters may be physically barred from the courtroom during certain pretrial proceed- 
One reason to examine the cameras-in-the-courtroom controversy now is the surprising rapidity with which the taboo is eroding. More than half the states-virtually all of which prohibited broadcasting or photography in their courts only five years ago-have either changed their rules to permit coverage or are actively studying the desirability of doing so. ${ }^{21}$ Rapid change always inspires reevaluation of the basic

ings, see Gannett Co. v. DePasquale, 443 U.S. 368 (1979), but Richmond Newsapers, Inc. v. Virginia, $100 \mathrm{~S}$. Ct. 2814 (1980), makes it clear that the press as well as the public has a first amendinent right to be present at the actual trial. Nevertheless, Richmond Newspapers left open the possibility that in some cases the interest in closure may outweigh the press's right to attend a trial. See $100 \mathrm{~S}$. Ct. at 2830 \& n.18. For that reason, this Article considers only the question of media access to those courts that are open to the general public, as opposed to those courts closed pursuant to a motion like that in Gannett.

21. An accurate list of those states that currently permit the use of television and other recording equipment on a permanent or experimental basis is difficult to compile because the numbers are growing steadily, and because many states are moving quickly from experimentation to permanent amendment of their old prohibitory rules.

At present, the following states have permanently adopted court rules or statutes that permit the press to cover trials and appellate arguments with electronic and photographic equipment: Alabama (Alabama Canons of Judicial Ethics, Canon 3A(7), (7A), (7B) (effective Feb. 1, 1976), printed in ALA. CODE tit. 23, at 542); Alaska (Canon 3A(7)(c) (effective Nov. 1, 1979), In re Canon 3A(7), 5 Media L. Rep. 2494 (Alas. 1979)); Colorado (Colorado Canons of Judicial Ethics, Canon 3A(8), (9), (10) (adopted Feb. 27, 1956)); Florida (Florida Code of Judicial Conduct, Canon 3A(7) (amended May 1, 1979)); Georgia (Georgia Code of Judicial Conduct, Canon 3A(8) (amended May 12, 1977), printed in 238 Ga. 855 (1977)); New Hampshire (Code of Judicial Conduct, Canon 3A(7) (amended Jan. 1, 1978)); Nortl Dakota (Code of Judicial Conduct, Canon 3A(7) (amended July 1,1980 ) (electronic and photographic coverage of appellate proceedings only)); Tennessee (Supreme Court Rule 43, and Code of Judicial Conduct, Canon 3A(7) (amended Feb. 22, 1979)); Texas (Texas Code of Judicial Conduct, Canon 3A(7) (adopted Nov. 9, 1976) (electronic recording of appellate arguments only)); Washington (Code of Judicial Conduct, Canon $3 \mathrm{~A}(7)$ (effective Sept. 20, 1976), printed in 87 Wash. 1119 (1976)); Wisconsin (Code of Judicial Ethics (amended June 21, 1979)).

In addition, the following states have instituted pilot programs permittiug electronic coverage on a trial basis: Arizona (Order Temporarily Suspending Rule 45, Rules of the Supreme Court, Code of Judicial Conduct, Canon 3A(7) (Apr. 16, 1979)); Cahfornia (In re California Rules of Court, 6 Media L. Rep. 1252 (Cal. Jud, Council 1980). See also National Center for State Courts, Electronic and Photographic Media Covcrage of Court Proceedings: An Annotated Bibliography 14-15 (Update No. 4, July 1979)); Idalio (Supreme Court Order, In re: Guidelines for Coverage of Supreme Court Proceedings (Oct. 18, 1978) (arguments before Supreme Court only)); Iowa (In re Modification of Canon 3A(7) of the Iowa Code of Judicial Conduct, 5 Media L. Rep. 2437 (lowa (1979)); Louisiana (Supreme Court Order Concerning Television and Court Rules and Regulations for Division B of the Ninth Judicial District Court for Rapides Parish (Feb. 23, 1978)); Minnesota (National Center for State Courts, supra, at 17 (arguments before Supreme Court only)); Montana (Supreme Court Order, In re Canon 35 of the Montana Canons of Judicial Ethics (Feb. 3, 1978)); Nevada (In re Rules Setting Forth the Standards of Conduct and Technology Governing Electronic Media and Still Ploto Coverage of Judicial Proceedings, 5 Media L. Rep. 2609 (Nev. Sup. Ct. 1980)); New Jersey (Supreme Court Order Concerning a Trial Prograin of Electronic Media Coverage of Court Proceedings (Mar. 15, 1979)); New Mexico (Code of Judicial Conduct, Canon 3A(7) (effective July 1, 1980), reported in News Notes, 6 Media L. Rep. No. 4 (May 27, 1980)); Ohio (Code of Judicial Conduct, Canon 3A(7) (effective Junc 1, 1979), printed in 58 Ohio St. xxxi (1979)); Oklaholna (Supreme Court Order, New Rule Change for Code of Judicial Conduct: Canon 3A(7) (Oct. 25, 1978)); Pennsylvania ((effective Oct. 1, 1980), reported in 
premises on which old rules rested and on which new rules should be constructed. In this case, one important premise for state courts to reconsider is the notion that modern technology is not entitled to first amendment protection when used to gather news about the workings of the courts. Ultimately, the change in state court practices will return that question to the Unitcd States Supreme Court, giving the Court an - opportunity to review both the validity of its position in Estes and the first amendment issues it failed to address im that case. ${ }^{22}$ In the 1980 term, the Court will hear Chandler v. Florida, ${ }^{23}$ a challenge by two criminal defendants to Canon 3A(7) of Florida's Code of Judicial Conduct. ${ }^{24}$ Under the Florida Canon, the judge permitted newsmen to televise and photograph the trial of two criminal defendants despite the defendants' objections. The defendants-appellants argue that the $\mathrm{Ca}$ non deprived them of their right to due process and a fair trial.

This Article suggests how the Supreme Court might best resolve the question of cameras in the courts. It proposes a first amendment analysis that would bring protections for modern communications technology in line with those protections traditionally accorded the print inedia. The proposed theory views a reporter's choice of news-

News Notes, 5 Media L. Rep. No. 32 (Jan. 22, 1980)); West Virginia (Guidelines for Camera Coverage of Trials in the Circuit Court of Monongalia County (effective Jan. 1, 1979)). Among states considering such experiments are Massachusetts, Oregon, and Rhode Island, National Center for State Courts, supra, at 14-22, and Maryland, reported in News Notes, 6 Media L. Rep. No. 4 (May 27, 1980). The New York Court of Appeals recently conducted a successful test of televising its own proceedings. N:Y.L.J., Oct. 23, 1979, at 1, col. 4. A Media Advisory Committee appointed by Chief Judge Cooke has recommended that New York permit televising of appcllate proceedings on a permanent basis and experiment for one year in televising civil trials. N.Y.L.J., June 4, 1980, at 1, col. 3. A New York statute, N.Y. Civ. Rights LAw \$ 52 (McKinney 1976), which prohibits televising proceedings at which witnesses may appear under subpoena, must be ainended before cameras can be used in New York trial courts.

A resolution of the state court chief justices recommending that the Code of Judicial Conduct in each state and federal jurisdiction be amended to permit electronic and photographic coverage of the courts prompted much of this activity. Conference of Chief Justices, Resolution I, adopicd Aug. 2, 1978, reprinted in In re Post-Newsweek Stations, Fla., Inc., 370 So. 2d 764, 791-92 (Fla. 1979).

22. The Conrt decided Estes solely on due process grounds.

A case raising issues similar to those in Estes was the 1979 trial in Florida of former law student Theodore Bundy for the inurder of two women students at Florida State University. The case attracted national attention and the trial was televised over the objections of Bundy, who was subsequently convicted. People v. Bundy, No. $79-10154$ (Fla. Cir. Ct. July 24, 1979), appeal docketed, No. 57,772 (Fla. Sup. Ct. Sept. 26, 1979); for a description of the case, sce N.Y. Times, June $26,1979, \S \mathrm{A}$, at 14, col. 3 ; id., July $25,1979, \S \mathrm{A}$, at 10 , col. 1 .

23. 366 So. 2 d 64 (Fla. Dist. Ct. App. 1978), prob. juris noted, 100 S. Ct. 1832 (1980).

24. The Chandler case, id., actually arose during Florida's experiment with its new Canon. The new rule was formally adopted in 1979. See In re Post-Newsweek Station, Fla., Inc., 370 So. 2d 764 (Fla. 1979). 
gathering techniques-ranging from memory to written notes or photographic and aural recording - as presumptively permitted when the reporter covers a public event, such as a trial.

Part I of the Article argues that all news-gathering techniques should enjoy a first amendment right of access to any governmental function otherwise open to the public. This right will be referred to as "the right of technological access." Given this first amendment right, a ban on cameras in the courtroom would not be permissible unless clear and substantial countervailing interests outweighed the reporter's interest in free choice of methods of coverage. Part II examines the public and constitutional imterests that allegedly justify the exclusion of cameras from the courtroom, and concludes that none of these interests supports the absolute bans that remain $\mathrm{m}$ force in a number of jurisdictions. Part III discusses the types of restrictions that may be imposed upon the use of cameras consistent with the proposed right of access. The government could impose narrowly drawn limitations on a particular news-gathering technique when distinctive attributes of the technique would interfere in a unique and identifiable way with other constitutional rights, or with significant public interests. The point of departure for this Article will be a critique of Estes v. Texas, ${ }^{25}$ the case that sanctioned the notion that television and the courtroom are per se inconipatible.

A reevaluation of Estes focuses primarily on the cameras-in-thecourtroom issue, but also carries implications for a broader right of access to public functions. The same restrictions that have been imposed on photographers and broadcasters in open court are also encountered at meetings of town councils, ${ }^{26}$ in the chambers of legislative bodies, ${ }^{27}$ and in the public activities of administrators and executive

25. 381 U.S. 532 (1965).

26. See Nevens v. City of Chino, 233 Cal. App. 2d 775, 44 Cal. Rptr. 50 (Dist. Ct. App. 1965); Sudol v. Borough of North Arlington, 137 N.J. Super. 149, 348 A.2d 216 (1975); Davidson v. Common Council of City of White Plains, 40 Misc. 2d 1053, 244 N.Y.S.2d 385 (Sup. Ct. 1963). All three cases involved efforts to prevent the use of mechanical devices to cover municipal government proceedings.

27. See, e.g., Sigma Delta Chi v. Speaker, Maryland House of Delegates, 270 Md. 1, 310 A.2d 156 (1973) (the press unsuccessfully challenged a Maryland State Senate rule prohibiting the use of recording devices and cameras in the chamber without the permission of the President of the Senate); Comment, The Right to Record and Broadcast Public Legislative Proceedings, $42 \mathrm{U}$. CHI. L. Rev. 336 (1975). The United States Senate does not permit cameras or recording of its public sessions except by special permission. Congress permitted debate over ratification of the Panama Canal Treaty to be broadcast on radio but not on television, S. Res. 268, 95th Cong., 2d Sess., 124 Cong. Rec. SI 102 (1978). See generally S. ReP. No. 630, 95th Cong., 2d Sess. (1978) (accompanying S. Res. 268)); TwENTIETH CENTURY FUnd TASK FORCE ON BROADCASTING AND the Legislature, Openly ARRived At 9-10 (1975). The House of Representatives in 1977 passed a resolution under which the House would provide audio and visual coverage of activities 
officers of government. ${ }^{28}$ Many of the justifications these government bodies give for limiting the news-gathering techniques used to report their activities are identical to, and were imspired by, the reasonimg that has kept modern coinmunications technology out of the courts. ${ }^{29}$ Hence, if the Estes rationale for excluding cameras from the courtroom falls, the right of technological access will expose other governmental bodies, as well as the courts, to the eye of the electronic media. Even if the Supreme Court reaffirms its position in Estes because it believes that the environment of the courts is particularly sensitive, a clear statement by the justices that the first amendment protects technological access would require governmental bodies other than the courts to reexamine carefully their bans on recording devices.

\section{The Case for a Constitutional Right of TECHNOLOGICAL ACCESS}

\section{A. The Myth of Estes.}

The assumptions about the court's power to exclude cameras derive from the broad reading generally given to Estes v. Texas. ${ }^{30}$ As a result of that decision, federal and state courts deciding whether to admit canneras and recording devices to trials and appeals have either ignored the possiblity of a constitutional question or have asserted that no right of technological access exists. ${ }^{31}$ Estes should not be read so

on the floor of the chamber for use by television, radio, and cable operators. H.R. Res. 866, 95th Cong., Ist Sess., 123 CoNG. REC. H11678 (1977).

28. In 1972, the Administrative Conference of the United States recommended that federal agencies develop a policy to permit radio and television broadcasters to use recording equipment to cover administrative proceedings. U.S. ADMIN. CONF., Recommendation 32, [1971-72] REPORT 77-78 (1972), codified at 1 C.F.R. $\$ 305.72-1$. The response, however, was sparse, U.S. ADMIN. CONF., [1972-73] REPORT 26-27 (1973). A recent check of the Code of Federal Regulations reveals little additional activity. See also CBS, Inc. v. Lieberman, 439 F. Supp. 862 (N.D. III. 1976) (the court refused to enjoin the State Commerce Commission from maintaining an unwritten rule against recording and filming public agency hearings).

29. See, e.g., CBS, Inc. v. Lieberman, 439 F. Supp. 862, 868 (N.D. Ill. 1976), which relies on Estes v. Texas, 381 U.S. 532 (1965), as precedent and refers to concerns about decorum, disruption of hearings by the use of recording equipment, the privacy interests of participants, and other factors comparable to those raised in the courtroom context. See Part I1, infra. See also 123 CONG. REC. HI1687 (1977) (remarks of Rep. Ryan) ("We are now about to change [Congress] from a forum to a theater"); JoINT COMM. ON CONGRESSIONAL OPERATIONS, 93D CONG. 2D Sess., Congress and Mass Communications: An Institutional Perspective 44 (Comm. Print 1974) (noting the concern over the distortion of the legislative process, the inability of viewers to interpret events that are broadcast, and the fear that legislators will "play" to cameras); Twentieth Century Fund TASK ForCe, supra note 27, at 21-25 (dissent by William A. Rusher) (television diminishes the importance of complex events rather than informing about them, and will therefore reduce public respect for the Congress).

30. 381 U.S. 532 (1965).

31. See Seymour v. United States, 373 F.2d 629, 632 (5th Cir. 1967); In re Acuff, 331 F. 
broadly. There is no clear reason to beheve that Estes, whatever it may have said about television or radio, denied constitutional protection to the use of still cameras or tape recorders. ${ }^{32}$ Even less reason exists to conclude that Estes pronounced a general rule about the permissible regulation of the newer media in settings other than the courtroom.

It is not even clear what Estes actually held about the use of broadcasting equipment in the courts. The sole question presented was whether Billy Sol Estes had been deprived of due process by the coverage of his pretrial hearmg and trial by broadcasters. ${ }^{33}$ Here the majority sphit. Justice Harlan took a narrower approach than his four brethren, holding only that the presence of television cameras per se violates due process in a "criminal trial of great notoriety." 34 The others decided, more expansively, that televising any crimmal case violates the constitutional rights of defendants.

Since Estes concerned the defendant's rights, and not those of the press, no first amendment claim was before the Court. ${ }^{35}$ The discussion of technological access in the opinion ${ }^{36}$ is therefore pure dictum. Furthermore, the majority opinion and Chief Justice Warren's concurrence in Estes may not have imtended to suggest that the Constitution guarantees the media no more than to have reporters physically present at the trial.

The opinion of the Court did state that "courts [cannot] be said to discriminate where they permit the newspaper reporter access to the courtroom. The television and radio reporter has the same privilege. All are entitled to the same rights as the general public. The news

Supp. 819,820 (D. N. Mex. 1971); In re Post-Newsweek Stations, Fla., Inc., 370 So. 2d 764, 774 (Fla. 1979) (all relying on Estes). Most of the recent court orders adopting temporary or permanent rules of technical access suggest that the rulings are discretionary with the courts and do not consider the possible first amendment interests. See, e.g., In re Canon 3A(7), 4 Media L. Rep. 263 I (Ohio Apr. 12, 1979); In re Canon 3A(7), 4 Media L. Rep. 1824 (Okla. Oct. 25, 1978). In announcing that the Georgia Supreme Court would revise its rules to permit photographic and electronic coverage, Chief Justice Nichols spoke only of a desire "to raise the public's appreciation for and understanding of our court system" as notivating the change. State of the Judiciary Address by Chief Justice Nichols to Georgia General Assembly (Feb. 21, 1977).

32. Accord, Bell v. Patterson, 279 F. Supp. 760, 769 (D. Colo.), aff'd, 402 F.2d 394 (10th Cir. 1968), cert. denied, 403 U.S. 955 (1971) (distinguishing still photography from television). Although still photographers were present at Estes's pretrial hearing and trial, 381 U.S. at 536-37, the Supreme Court did not decide whether their presence also interfered with the defendant's rights.

33. 381 U.S. at 535. Estes was on trial for swindling. Id. at 534. Despite a change of venue, the trial attracted a great deal of public attention. Id. at 535-36. Estes sought reversal of his conviction solely because of the televising of his trial. The Court held that televising per se denied Estes due process, and reversed the conviction. Id. at 543-44, 552.

34. Id. at 587 (Harlan, J., concurring).

35. Id. at 534-35; id. at 614 (Stewart, J., dissenting).

36. Id. at $539-40$. 
reporter is not permitted to bring his typewriter or printing press." 37 But the majority immediately qualified this blunt assertion. The Justices asserted that radio and television equipment was barred solely because it was, as then operated and perceived, a hazard to a fair trial; they then added that when the hazard no longer exists "we will have another case."38 Thus, Estes cannot be understood unequivocally to deny a possible first amendment interest of broadcasters in the use of their equipment. Rather, the case might be read to inean that in a balance of conflicting constitutional claims, due process prevailed. ${ }^{39}$

The concurring opinion by Chief Justice Warren supports this reading. Warren agreed that the reason for prohibiting caineras from the courtroom is that their presence endangers the right to due process of law. ${ }^{40}$ Only Justice Harlan appears to have concluded that technological access does not raise a first amendment issue. ${ }^{41} \mathrm{He}$ argued that the ability of the press to use any method of memorializing what they observed at trial depended upon the court's discretion, and he intimated that the Constitution provides no right to bring the reporter's paraphernatia-including pencils and and notebooks-into the courtroom. ${ }^{42}$

Of the Justices who decided Estes only Stewart, Brennan, and White remain on the Court today. All dissented in that case, ${ }^{43}$ explicitly identifying the first amendment issue that the majority neglected. Justice Stewart, writing for the dissenters, cautioned that in deciding whether Estes received a fair trial, "we nnove in an area touching the realm of free coinmunication ... . I would be wary of imposing any per se rule which, in the light of future teclmology, inight serve to stifle or abridge true First Amendment rights." 44 While Stewart did not

37. Id. at 540 .

38. Id. See also id. at 595-96 (Harlan, J., concurring).

39. Justice Harlan explicitly stated in his concurrence that he applied a balancing test. $I d$. at 587. He also suggested, however, that technological access does not raise a first amendment question, so that he appears to have weighed the sixth amendment interests of a defendant against a nonconstitutional interest of the press and public. Id, at 589-90 (Harlan, J., concurring).

40. Id. at 584 (Warren, C.J., concurring).

Just as an ordinary citizen might be prohibited from using field glasses or a motion picture camera in the courthouse because by so doing he would interfere with the conduct of the trial, representatives of the press and broadcasting industries are subject to similar limitations when they attend court. Since the televising of criminal trials diverts the trial process from its proper end, it must be prohibited.

Id. (emphasis added). Neither this concurrence nor the majority opinion suggested that the first amendment was not implicated. At most, one could say that the nature of the press's competing interest was not defined.

41. Id. at 589-90 (Harlan, J., concurring).

42. $I d$.

43. See id. at 601 (Stewart, J., dissenting, jomed by Black, Brennan, and White, JJ.).

44. Id. at 604. See also id. at 614-15. 
define the precise nature of the rights at issue, what he wrote did suggest that he was concerned with technological access. He asserted that the first amendment creates a presumption that favors the press's presence, including the presence of its technological tools. When unresolved issues of fact regarding the effects of press presence are involved, he argued, the press should receive the benefit of that presumption. 45 One might infer that Justice Stewart understood the first amendment to forbid per se restrictions on the ability of reporters to employ the tools of their trade in covering a public event in the absence of clearly demonstrated harn to other substantial interests.

Chandler v. Florida, ${ }^{46}$ the case to be decided this term, will provide the Court with its first opportunity to reconsider the Estes problem. In the fifteen years since Estes was decided, only two Supreme Court cases have addressed problems concerning the use of modern news-gatlering technology. ${ }^{47}$ Neither involved the use of cameras in the courtroom. Moreover, neither served to clarify the post-Estes uncertainty about a possible first amendment right of technological access.

The first of these two cases, Nixon v. Warner Communications, Inc. ${ }^{48}$ grew out of the criminal trial of several former White House aides for conspiracy and obstruction of justice. ${ }^{49}$ Warner Communications sought to reproduce portions of the twenty-two liours of tape recordings of presidential meetings and telephone conversations that had been introduced into evidence at the trial. Warner presented arguments on common law, first amendment, and sixtl amendment grounds. The Court found that the common law right to inspect and copy judicial records did not extend to the nnaking of an aural recording of a tape. Warner's first ainendment argument was similarly rejected. The Court, citing Estes, stated that the press's right of access went no further than the general public's right. The public at large had been permitted to hear the tapes but had never been given access to the tapes themselves. ${ }^{50}$

Finally, Warner urged the Court to grant access to the tapes because denial of access would violate the sixth amendment's public trial guarantee.51 The Court, assuining for the sake of argument that

45. Id. at 615 .

46. 366 So. 2 d 64 (Fla. Dist. Ct. App. 1978), prob. juris. noted, 100 S. Ct. 1832 (1980).

47. Houchins v. KQED, Inc., 438 U.S. I (1978); Nixon v. Warner Communications, Inc., 435 U.S. 589 (1978).

48. 435 U.S. 589 (1978).

49. Id. at 592.

50. Id. at 609.

51. Id. at 610 . 
Warner had standing to raise this claim, rejected it, relying on Estes to support a conclusion that "there is no constitutional right to have [either hive or taped] testimony rccordcd and broadcast." 52 If the press and public have no right to record the actual trial on film or tape, the Warner Court reasoned, then a fortiori they can have no right to make an out-of-court recording of taped testimony. But the reliance of the Warner majority on Estes is unjustified. Estes did not decide that there is no first amendment right to record trials; rather, the case held only that recording would not be permitted when it threatened a defendant's right to due process of law. 53

Warner should be viewed skeptically as a statement about the existence or nonexistence of the right of technological access, and not merely because it makes questionable use of precedent. First, Warner Communications could not copy the tapes without physical access to them, and the Court pointed out that physical access to judicial records traditionally lias been subject to limitation at the discretion of the judge. ${ }^{54}$ Second, the case dealt with a highly unusual and sensitive set of facts and parties. The party seeking to prevent reproduction of the tapes was a former President of the United States, thus implicating difficult issues of executive privilege. Under such circumstances, the Court niay, understandably, have been less concerned with its development of the law than with its desire to reach an appropriate result.5s

In Houchins v. KQED, Inc. ${ }^{56}$ a San Francisco radio and television broadcaster and local branclies of the National Association for the Advancement of Colored People claimed that a series of limitations on their ability to visit and report on conditions in the Alameda County Jail in Santa Rita, California, violated the first amendment. KQED listed among its complaints an objection to the warden's refusal to perimit reporters to bring cameras or tape recorders into the jail.s7 The Court held, four to three, that the warden's refusal to allow the press

52. Id.

53. See notes 33-39 supra and accompanying text.

54. 435 U.S. at $598-99$.

55. Justice Holmes had in mind such cases when he wrote the often-quoted line, "Great cases like hard cases make bad law." Northern Sec. Co. v. United States, 193 U.S. 197, 400 (1904) (Holmes, J., dissenting). Some evidence that the Supreme Court found Warner to be one such "hard case" may be found in the emphasis in the majority and dissenting opinions on the unusually sensitive nature of the problem to be resolved. See 435 U.S. at 603, 615 (Stevens, J., dissenting). Further support for the notion that Warner should be viewed as sui generis may be gleaned from the fact that when the Court decided the next case involving the media's use of cominunications technology to gather news, no member of the Court cited Warner as precedent. See Houchins v. KQED, Inc., 438 U.S. 1 (1978).

56. 438 U.S. 1 (1978).

57. Id. at 5 . 
and the public to visit the so-called Greystone area of the jail or to interview prisoners did not violate KQED's first amendment rights. But Justice Stewart, who concurred in the judgment, agreed witl the three dissenters ${ }^{58}$ that the trial court acted properly in ordering the warden to permit the press to bring in its cameras, tape recorders, and video equipment. ${ }^{59}$ Justice Stewart exphicity stated that once the jail was open to the press, the press had a first amendment right to "effective" access to the facility. Effective access would require the warden to allow cameras and tape recorders when they created no serious risks to prison security.$^{60}$

The Supreme Court has therefore not definitively decided whetler the first amendment includes a riglit of technological access. This Article argues that such a right is implicit in the first annendment and that it warrants recognition.

\section{B. The Derivation of First Amendment Protection for Technological Access.}

In the past, when parties have argued in favor of allowing the press to use cameras to cover trials, they have relied on two legal theories: that bans on the use of media technology violate the equal protection clause of the fourteenth amendment, and that sucli bans are prior restraints on speech in violation of the first amendunent. Neither argument has been widely accepted.

The equal protection rationale has been that because print reporters may use notebook and pen to record dialogue and impressions, the reporters in otler media should be free to use the equipment appropriate to their media. If this kind of evenhanded treatunent is denied, reporters are not treated in a functionally equal way: none but the traditional print journalists may exploit the full potential of their medium of commumication.

The Supreme Court rejected this argument in Estes. Justice Clark, writing for the Court, made it clear that as long as courts treat television reporters and photojournalists the same as print journalists-that is, permit them to be present in the court and take notes-they have

58. Justices Stevens, Brennan, and Powell dissented. Id. at 19. Justices Marshall and Blackmun took no part in the consideration or decision of the case. Id. at 16 .

59. Id. at 16 (Stewart, J., concurring). Justice Stewart concurred in the reversal of the prelimmary injunction issued by the district court only because he found the injunction overbroad. He did not foreclose the possibility of more limited injunctive relief on remand in order to ensure press access.

60. Id. at 17 (Stewart, J., concurring). 
received equal protection. ${ }^{61}$ This view is entirely consistent with the Court's strict treatment generally of equal protection. The equal protection clause, as the Court interprets it, does not guarantee functional equality; it merely ensures that insofar as individuals are similarly situated, they will receive similar treatment. The government remains free to give dissimilar treatment to individuals insofar as they differ in any significant way. ${ }^{62}$

The prior restraint argument was not addressed by the Court in Estes, but this theory is also imperfect. A prior restraint directly interferes with the dissemination of information once it has been obtained. Thus, if a court seized a videotape of a trial after it had been made, or ordered a station not to air it, a prior restraint would clearly be involved. ${ }^{63}$ But a refusal to allow the videotaping to take place at all, while it inay have the same ultimate affect as a prior restraint, does not fit squarely within the traditional definition, and inost courts have been unwilling to treat such refusals as prior restraints. ${ }^{64}$

This Article proposes a third approach, which flows froin the general premise that the first amendment protects speech in all its aspects froin interference by the government except when compelling reasons exist for imposing carefully tailored restrictions. To put it simply, speech activities are presumed to be legitimate. ${ }^{65}$ One aspect of the protected activity we call speech is the process of gathering information

61. 381 U.S. at $539-40$.

62. A graphic example of the difference between strict and functional equal protection and how the Court views the problem is found in Geduldig v. Aiello, 417 U.S. 484 (1974). In that case, plaintiffs objected to California's exclusion of disability coverage for normal pregnancy from a state disability insurance plan that was otherwise comprehensive and that covered every conceivable disability which could befall a male. If the Court treated working women as functionally equal to working men, it would have ruled that disabilities peculiar to women could not be singled out for exclusion from an insurance program designed to secure incomes of workers who were physically unable to work. Instead, the Court held for the state, finding that it was no violation of the rule of "similarly situated, similarly treated" to treat women differently from men as to a characteristic exclusive to their gender. Id. at 494. See generally Comment, Gelduldig v. Aiello: Pregnancy Classifications and the Definition of Sex Discrimination, 75 Colum. L. Rev. 441 (1975).

63. See, e.g., United States v. CBS, Inc., 497 F.2d 102 (5th Cir. 1974) (liolding that a court order proscribing the publication of sketches of courtrooin scenes was an invalid prior restraint).

64. See, e.g., CBS, Inc. v. Lieberman, 439 F. Supp. 862, 865-66 (N.D. Ill. 1976) (an order banning the television filming of an administrative hearing was not a prior restraint). See also Umited States v. CBS, Inc., 497 F.2d 102 (5th Cir. 1974); Seymour v. United States, 373 F.2d 629, 631-32 (5th Cir. 1967). Both cases strongly imply, although they do not explicitly hold, that orders banning sketching and photography are not prior restraimts. But see Dorfman v. Meiszner, 430 F.2d 558 (7th Cir. 1970) (a rule banning photography and broadcasting anywhere in or around a federal building that contains a court was an invalid prior restraint).

65. This premise is derived not from a particular case but from the generally preferred position which speeeh activities enjoy under the American constitutional scheıne. See note 139 infra. 
and selecting a form in which it will be communicated to others. ${ }^{66}$ This process is called, in relation to the press, news-gathering.

The Supreme Court has recognized that news-gathering, as a necessary precursor of communication, nnust enjoy some protection under the first amendment, although it has yet to delineate the precise nature and scope of that protection. In Richmond Newspapers, Inc. v. Virginia, ${ }^{67}$ the Court for the first time recognized a first aniendment right to be present at trials, and suggested that the Constitution may also provide a right to attend other government proceedings and to obtain other important information fron the government. How far the Court will extend the first amendent right to information is uncertain, particularly in view of its reluctance prior to Richmond Newspapers to force the government, absent a statutory directive, to divulge its operations to the public and the press. 68

The recognition in Richmond Newspapers that the first amendment gives a right to gather information from government is entirely consistent with a constitutional right of technological access. The right proposed here, however, does not depend upon a constitutional right to be present at a proceeding or event. Technological access should be available as of right whenever the government opens a proceeding to the public, even if it does so at its discretion rather than at the conunand of the Constitution. Given the uncertain scope of Richmond Newspapers, there may be niany important events that the Court would not, as a constitutional inatter, order the government to open. Nevertheless, for pohtical reasons or by custom, the government will open these events voluntarily. In these situations, recognition of a right of teclinological access would allow the press to carry out its role as surrogate for those who cannot attend by enabling reporters to meniorialize the information they obtain in the form they choose. ${ }^{69}$ This choice is so closely

66. Numerous cases suggest that the Supreme Court ordinarily will protect the speaker's right not merely to communicate but also to select the form in which the communication will occur and to engage in activities which are necessary to produce speech. See, e.g., Buckley v. Valeo, 424 U.S. 1, 16 (1976) (spending money to support political campaigns is protected both as speech and as a neccssary predicate for speech); Cohen v. Cahifornia, 403 U.S. 15 (1971) (words written on a jacket are a form of protected speech); Tinker v. Des Moines Independent Community School Dist., 393 U.S. 503 (1969) (wearing a black armband as an antiwar symbol is protected speech). But cf. United States v. O'Brien, 391 U.S. 367 (1968) (suggesting but not deciding that draft card burning may not be speech for first amendment purposes).

67. 100 S. Ct. 2814, 2828-29 (1980); id. at 2831 (Stevens, J., concurring).

68. See Houchims v. KQED, Inc., 438 U.S. 1 (1978); Pell v. Procunier, 417 U.S. 817 (1974); Saxbe v. Washington Post Co., 417 U.S. 843 (1974). Cf. Gannett Co. v. DePasquale, 443 U.S. 368 (1979) (the sixth amendment right to a pubhc trial does not give the press an enforceable right to attend pretrial hearings). An example of a statutory right to obtain imformation from the government is that provided by the Freedom of Information Act, 5 U.S.C. $\S 552$ (1976 \& Supp. II 1978).

69. This Article does not purport to decide whether the government can ever condition access 
akin to recognized first amendment rights, such as the right to communicate through a painting or a film rather than an essay, ${ }^{70}$ that there is no clear reason to deny it. Recognition of teclmological access as a first amendment right would be of primary importance to photographers and to reporters for the electronic media, but print journalists, scholars, and other citizens would also benefit, both as speakers and as members of the audience.

At least a rudimentary recognition of technological access already exists in Supreme Court, lower federal court, and state court opinions. The cases acknowledge that the government cannot interfere with the rights of individuals to make written notes to aid them $\mathrm{m}$ transmitting infornation to others. ${ }^{71}$ Courts have also generally agreed that the press may sketch scenes of the courtroom while the trial is in progress. ${ }^{72}$ They have usually assumed, however, that this mimimal degree of technological access fully satisfies the first amendment. ${ }^{73}$

to information upon the recipient's willingness to forego the right to record it in a manner of his choice. For example, the President might agree to grant an interview to a small group of reporters on the condition that they not bring cameras or tape recorders. There might be reasons to justify this restriction, while nevertheless finding similar restriction imposed by the President on media covering a public speech or public news conference to be invalid. This Article will confine itself to considering those events the public traditionally may attend. A trial is such an event. The right of the public to attend trials was customary under Anglo-American law, and has now been accorded first amendment protection. Richmond Newspapers, Inc. v. Virginia, $100 \mathrm{~S}$. Ct. 2814 (1980). Other proceedings may be open by statute to the public and press. See, e.g., 5 U.S.C. $\$ 552 \mathrm{~b}$ (1976) (the proceedings of federal agencies are to be conducted in public except under enumerated circumstances). Still others may be open by custom or become de facto public because the government has chosen to admit a large cross-section of individuals. An example would be a press conference open to accredited journalists.

70. See note 6 supra and notes $92-93$ infra.

71. A federal district court, reviewing a claim of technological access to an administrative proceeding stated: "Defendants ... concede a First Amendment Right in those attending the hearing to record or memorialize that which they see and hear by paper and pencil. No authority to the contrary has coine to our attention." CBS, Inc. v. Lieberman, 439 F. Supp. 862, 866 (N.D. III. 1976). The author's search has similarly failed to uncover contrary authority, except for one statement by Justice Harlan in his concurring opinion in Estes, 381 U.S. at 590; see text accompanying note 42 supra. The Maryland Court of Appeals in Sigma Delta Chi v. Speaker, Maryland House of Delegates, $270 \mathrm{Md} .1,8,310$ A.2d 156, 160 (1973), suggested that a ban on the use of pen and paper would be unconstitutional because it might "frustrate all effective communication." (Emphasis in original.) The Court, however, found a ban on tape recorders only "a mere inconvenience." See also Nevens v. City of Chino, 233 Cal. App. 2d 775, 778, 44 Cal. Rptr. 50,52 (1965) (an attempt to bar the use of a tape recorder to record public governmental functions would constitute an improper use of government power). But cf. Pell v. Procunier, 417 U.S. 817, 823-24 (1974) (suggesting that while the availability to prisoners of one mode of cominunication does not autoinatically extinguish an interest in other modes, the existence of alternatives is relevant in deciding if the restriction violates the first amendment).

72. United States v. CBS, Inc., 497 F.2d 102 (5th Cir. 1974); In re NBC, 64 N.J. 476, 317 A.2d 695 (1974).

73. See, e.g., Estes v. Texas, 381 U.S. at 539-40; CBS, Inc. v. Lieberman, 439 F. Supp. 862 (N.D. Ill. 1976); Sigına Delta Chi v. Speaker, Maryland House of Delegates, 270 Md. 1, 310 A.2d 156 (1973). 
Even those courts that have recognized a broader first amendment right to choose an appropriate method of news-gathering have said little to articulate the scope of the right or the reasons for it. Before Estes, two of the three state courts that favored televised trials specifically held that the first amendment guarantees technological access. ${ }^{74}$ The Oklahoma Crimmal Court of Appeals simply found that the first amendment ensures a right to equal treatment in news-gathering, by which it meant the ability to use the technological tools appropriate to each medium. ${ }^{75}$ The Georgia Court of Appeals articulated more thoroughly its reasons for ruling that a ban on technological access violates the Constitution:

We . . . recognize that there are inherent differences in the methods used by these newer types of newsgathering media and that they should not be so hemmed and hedged about as to be hampered in the exercise of the natural advantages which they enjoy, to wit, the transcribing on tape of the actual voices of those making the news or on film or "videotape" not only their voices but their images. ${ }^{76}$

Simce Estes, however, most courts have been reluctant to pursue and refine this line of analysis, even outside the context of criminal trials. Some have specifically cited Estes as controlling precedent; even when Estes is not specifically cited, however, one may reasonably presume its influence. ${ }^{77}$

In spite of Estes, a few federal and state courts have continued to hint that the Constitution offers at least some protection to the reporter's right to gather news by the means of his choice. In 1969, the Court of Appeals for the Seventh Circuit reversed a trial court's dismissal of a section $1983^{78}$ action alleging that the City of Chicago and the Chicago police imterfered with the plamtiff's attempt to photograph demonstrations at the 1968 Democratic National Convention. ${ }^{79}$ The

74. Hudson v. State, 108 Ga. App. 192, 196, 132 S.E.2d 508, 510 (1963) (the court, however, held that a defendant's objection to the presence of a radio microphone should have been sustained because of the priority of the defendant's right of a fair trial); Lyles v. State, 330 P.2d 734, 740-41 (Okla. Crim. App. 1958). A third state, Colorado, declined to adopt Canon 35 of the ABA's Canons of Judicial Ethics, see note 250 infra, because the rule conflicted with the free speech and public trial provisions of the Colorado Constitution. In re Hearings Concerning Canon 35 of the Canons of Judicial Ethics, 132 Colo. 591, 296 P.2d 465 (1956).

75. Lyles v. State, 330 P.2d 734, 740-4I (Okla. Criin. App. 1958) (televising of criminal trial).

76. Hudson v. State, 108 Ga. App. 192, 196, 132 S.E.2d 508, 510 (1963) (radio broadcast of criminal trial).

77. See note 31 supra.

78. 42 U.S.C. § 1983 (1976).

79. Schnell v. City of Chicago, 407 F.2d 1084 (7th Cir. 1969). Accord, Channel 10, Inc. v. Gunnarson, 337 F. Supp. 634, 638 (D. Minn. 1972) (a declaratory judgment that police acted improperly in seizing a television camera and film from a reporter covering a burglary): "Defendants have made no claim before this court that [the reporter] was in an improper place and it 
court concluded that "the complaint sufficiently alleges that constitutionally protected activity was and continues to be interfered with by the nained defendants . . ." 80 It did not elaborate, however, on the nature of the constitutional interest in taking photographs. In 1974, the Court of Appeals for the Fifth Circuit upset a ban on the sketching of courtrooin proceedings. The court found that sketching was neither obtrusive nor disruptive, and that the ban, which "touches on matters protected by the First Amendment," could not stand. ${ }^{81}$ Again the court did not explore the question further. New Jersey and California courts have also held that inunicipaities acted arbitrarily and capriciously in barring the use of tape recorders at public meetings of local government, finding that the rules infringed indirectly but significantly upon the first amendment without any reasonable countervailing public interest to justify that infringeinent. 82 They, too, said little inore.

Thus far, the inost cogent exploration of the issue has been inade by the sole Supreine Court Justice to grapple with the question of whether the press should have a protected right to gather news with cameras and other equipınent. Justice Stewart, who has been particularly intcrested in atteinpting to establisli an independent function for the press clause of the first ainendment, ${ }^{83}$ argued in Houchins v. KQED, $I n c^{84}$ that the press must be free to bring caineras and sound equipinent inside the county jail so that the reporters can convey "the jail's sights and sounds to those who cannot personally visit the place."85 This accominodation is required, Stewart says, because the Constitution "requires sensitivity" to the critical role played by the press in American society and to "the special needs of the press in performing it effectively." 86 Stewart explained techological access as a right essential for effective news-gathering.

A failure to adopt Justice Stewart's view of the right to gather news will prevent modern communicators from fully exploiting the capabilities of their inedia. This failure will impose upon inedia that are capable of conveying sights and sounds the methodology that was com-

seems that employees of the news media have a right to be in public places or on public property to gather information, photographically or otherwise."

80. Schnell v. City of Chicago, 407 F.2d 1084, 1086 (7th Cir. 1969).

81. United States v. CBS, Inc., 497 F.2d 102, 107 (5th Cir. 1974).

82. Nevens v. City of Chino, 233 Cal. App. 2d 775, 778, 44 Cal. Rptr. 50, $51-52$ (1965); Sudol

v. Borough of North Arlington, 137 N.J. Super. 149, 155, 348 A.2d 216, 218 (1975).

83. See Stewart, “Or of the Press," 26 Hastings L.J. 631 (1975).

84. 438 U.S. 1 (1978).

85. Id. at 17 (Stewart, J., concurring). This notion was adopted in Richmond Newspapers, Inc. v. Virginia by Chief Justice Burger, who stressed that media act as "surrogates for the public." $100 \mathrm{~S}$. Ct. at 2825 .

86. 438 U.S. at 17. 
pletely satisfactory only when media were limited to the printed word. When the first amendment was adopted, the mass communicators were the publishers of eighteenth century broadsheets and pamphlets; now they are the national television and radio networks. The Supreme Court firmly recognizes that speech can occur in a variety of forms, ${ }^{87}$ many of which were unknown or arguably unpalatable to the framers. ${ }^{88}$ The decision to himit constitutional protection of news-gathering to the techniques of two centuries ago is therefore out of harmony with the Supreme Court's own view of the fiexibility of the first amendment.

This Article attempts, therefore, to expand upon Justice Stewart's suggestion in Houchins. It articulates the reasons why the choice of a method of news-gathering is an integral part of freedom of speech and, as such, should enjoy constitutional protection. The argument depends on an analysis both of the function and purpose of the first amendment, and of the inherent nature of the various media.

The outer reaches of the protection of free speech remain vague, and no single theory of free press and free speech commands universal acceptance. ${ }^{89}$ Scholars and judges agree, however, that the first amendment was designed to enhance and protect participation by the individual citizen in the process of self-government. ${ }^{90}$ Freedom to discuss and to criticize federal, state, and local government is the very bedrock of the amendment. ${ }^{91}$ Many forms of communication that are not explicitly political also nourish intelligent participation in a democratic society; for that reason, the Supreme Court has evolved a system of protections that encompasses speech diverse in content and form. Novels, painting, and drama, ${ }^{92}$ communications that entertain and

87. See note 6 supra and note 92 infra.

88. See Gellhorn, Dirty Books, Disgusting Pictures, and Dreadful Laws, 8 GA. L. Rev. 291, 296-97 \& n.21 (1974), and Henkin, Morals and the Constitution: The Sin of Obscenity, 63 Colum. L. REv. 391 (1963), for discussion of general prohibitions against blaspheny in the states at the time the Constitution was franed. Such laws would now be deened to violate the first amendinent. See generally L. LeVY, LEGACY OF SUPPRESSION (1960) for the theory that the frainers of the first amendinent intended solely to create a no prior restraint rule.

89. See generally Emerson, Toward a General Theory of the First Amendment, 72 Y ALE L.J. 877 (1963).

90. See, e.g., id. 882-83; Meiklejohn, The First Amendment Is An Absolute, 1961 S. CT. Rev. 245, 255; Chafee, Book Review, 62 Harv. L. Rev. 891,896 (1949). See generally Brennan, The Supreme Court and the Meiklejohn Interpretation of the First Amendment, 79 HARv. L. Rev. 1 (1965); Wellington, On Freedom of Expression, 88 YALE L.J. 1105 (1979).

91. See New York Times Co. v. Sullivan, 376 U.S. 254, 269-70 (1964).

92. "Motion pictures are of course a different medium of expression than the public speech, the radio, the stage, the novel, or the magazine. But the First Amendinent draws no distinction between the various methods of communicating ideas." Superior Films, Inc. v. Department of Educ., 346 U.S. 587, 589 (1954) (per curiam) (Douglas, J., concurring). 
communications that inforın, ${ }^{93}$ all fall within the realm of protected expression.

Recognizing the range and breadth of forms in which speech occurs, the law has responded by extending protection to newer communication technologies as they develop. Despite soine anomalous holdings, ${ }^{94}$ the Supreine Court has held that movies, radio, and television all coine within the purview of the first amendment. ${ }^{95}$ The Court has thus far failed to consider systematically the relationship between the ineans used to produce speech and the speech itself. Yet technological advances have altered not inerely the facility with which we cominunicate, but the content of the cominunication as well. A few exainples illustrate this point. Many early societies, when they developed a written language, used tablets of clay or stone to memorialize their writings. ${ }^{96}$ The invention of early papers made from rag, parchinent, or papyrus opened an entirely new dimension in communication because written speech could be made portable, private, and far more discursive. ${ }^{97}$ Written language becaine a suitable vehicle for artists and interpretive scholars. ${ }^{98}$ The invention of the printing press added another dimension to the range of coinununication because manuscripts no longer needed to be laboriously hand copied; books therefore ceased to be the private preserve of princes of church and state. With the advent of widespread literacy, spurred by the printing press, the nature of books changed to respond to a new audience. The prelates and nobles

93. "We do not accede to appellee's suggestion that the constitutional protection for a free press applies only to the exposition of ideas. The line between the informing and the entertaining is too elusive for the protection of that basic right. . . . What is one man's amusement, teaches another's doctrine." Winters v. New York, 333 U.S. 507, 510 (1948). See also Joseph Burstyn, Inc. v. Wilson, 343 U.S. 495, 501-02 (1952).

94. See notes 7-15 supra and accompanying text.

95. Red Lion Broadcasting Co. v. FCC, 395 U.S. 367, 388-90 (1969) (broadcasting is covered by the first amendment); Joseph Burstyn, Inc. v. Wilson, 343 U.S. 495, $501-02$ (1952) (movies); United States v. Paramount Pictures, Inc., 334 U.S. 131, 166 (1948) ("moving pictures, like newspapers and radio, are included in the press whose freedom is guaranteed by the First Amendment").

96. Minoan Linear A and B scripts were inscribed on clay tablets; the Hittites, too, used clay tablets as writing material. P. Mackendrick, The Greek Stones SPeak $81-89$ (1962). The earliest Egyptian hieroglyphs are found on seal stones, stone vases, and on wood or clay boards. J. White, AnCIent Egypt: Its Culture ANd History 87 (1970).

97. Paper, $\mathrm{m}$ the modern sense, was invented by the Chinese, probably at the beginning of the second century. U.S. Librare of Congress, Papermaking 8 (1968). It was not used in Europe, where books contimued to be written on parchment, until the 12th century; modern paper was introduced to Europe by the Moorish conquerors of Spain. Id. 18.

98. Early stone and clay writings, such as the Linear A and Linear B tablets, were used primarily to make mventories and lists. The Homeric poems appear to have developed through an oral tradition, and not from early stone and clay writings, which give no evidence of being used for purposes in any sense "literary," either in content or style. P. MACKENDRICK, supra note 96, at 89. 
who commissioned medieval manuscripts would hardly have encouraged a novelist like Daniel DeFoe or a social critic like Thomas Paine. ${ }^{99}$

Well before the invention of radio and television, the evolution of modern communications technology mfluenced the content of speech. The photograph became commonplace by the middle of the nineteenth century, and journalists quickly adopted the camera to cover the Crimean War and the Civil War. ${ }^{100}$ Those journalists produced a documentation of tragedies that remams stark and moving to modern viewers. The invention of the telegraph also changed the character of communications by transforming the local newspaper into a national and international disseminator of news, and by including isolated towns and villages in a national and international communications network. ${ }^{101}$ Motion pictures added a further refinement by communicating images in action. ${ }^{102}$

The various communications media-television, radio, photography, and the printed word-do not produce speech that is interchange-

99. By the 14th Century, families that had grown wealthy in the pursuit of commerce joined the nobility and the clergy as part of the small clientele for privately owned religious books, chivalric romances, and allegories. B. TuCHMAN, A DISTANT MIRror 453 (1978). Writing during the Middle Ages relied primarily on commissions and patronage support. See id. 238. The development of printing in the middle of the 15 th Century radically changed the picture. Id. 594-95. Prior to the invention of movable type,

texts in private ownership were the sole source of knowledge and reproduction of the work. Simultaneous duplication of copies, in anticipation of further sales, was undertaken by stationers only when a book became well-known and frequently wanted. It was not until printing that large-scale speculative book production and marketing became possible, from which arose the system of directly commissioning or accepting work from authors and translators, who are remunerated according to the number of copies sold or likely to be sold, instead of the old method of request, presentation, and reward between amateurs (neither authors nor patrons regarding literature as their main vocation or source of profit).

Doyle, The Social Context of Medieval English Literature, in THE AGE OF CHAUCER 81 (B. Ford ed. rev. ed. 1959). See also J. Servan-Schreiber, supra note 16, at 165-67.

100. B. Newhall, The History of Photography 67 (1964). For a capsule history of early photojournalism, see id. 67-81.

101. According to one commentator, 19th Century technology was what transformed the press into "a mass audience medium." D. Shaw, Technology: Freedom for What?, in MASS MEDIA AND THE NAtional ExPERIENCE 64 (R. Farrar \& J. Stevens eds. 1971). Shaw attributes the transformation to the invention of the high speed power press, improvement in paper manufacture, and the invention of the telegraph, which permitted the creation and growth of the news wire services. Id. 75 .

102. Thomas A. Edison and his assistant, William Dickson, perfected the motion picture between 1889 and 1891. T. RAMSAYE, A Million AND ONE Nights: A History of the Motion Picture Through 1925, at 65-73 (1926). The earhest commercial films were 50 feet or less in length, $i d$. 85; movies were not successfully projected onto a screen until about 1895 . Id. 129. By the end of the century, this new medium had been adopted by journalists who made the first motion picture documentaries. Reporters fihned troops departing for the Spanish-American War in 1897, and two years later captured on film a fire in the Windsor Hotel in New York City, in which 45 persons died. Id. 389-93. 
able. They engage our senses and our intellects in different ways. An historian of photography verbalized this difference in describing the impact of a Civil War photograph: "This man lived; this is the spot where he fell; this is how he looked in death. There lies the great psychological difference between photography and the other graphic arts; this is the quahity which photography can impart more strongly than any other picture making." 103 Voice recordings also engage our understanding not only through the words we hear but also through intonation, pace, and volume; films and television engage our visual and aural senses simultaneously. Because no one inediuin completely conveys all sense and feeling, the speaker's choice of how to present an idea or observation is a crucial aspect of the decision about what he or she will say.

Even the physical characteristics of each medium affect the nature of the communication for both speaker and audience. The print media are bounded by space; the electronic media are bounded by time. Newspapers, books, and magazines communicate by words primted on pages of fixed dimension and number. Literate "hearers" can read and reread, analyzing and clarifying their perceptions. Illustrations and photographs may be added to express what words do not adequately convey. Television and radio, by contrast, are confined by time, and cannot rely on the accumulation of descriptive word patterns. Were a radio or television reporter to adopt the technique of the print journalist, the atteinpt to duplicate orally the prose in a brief newspaper story would consume a substantial portion of a typical half hour news broadcast. Reporters for these media must, therefore, mix words with sounds and pictures in order to portray the events about which they report. Since audienccs vary in their understanding of different forms of communication, the availability of information from a variety of media protects not only the interests of the speaker but the interests of the hearer as well. A rule of constitutional law that treats the written word as the measure of free speecl will effectively favor the most literate audiences and will undervalue the interests of those who comprehend best visually and aurally.

Because each medium possesses a unique capacity to communicate, government restrictions on the choice of media used to record and

103. B. Newhall, supra note 100, at 71 . See also R. Schuneman, Photographic Communica. tion: An Evolving Historical Discipline, in MASS MEDIA AND THE NATIONAL ExpERIENCE 130-58 (R. Farrar \& J. Stevens eds. 1971), for an evaluation of the unique contribution of visual information through the medium of photography. Schuneman notes, for example, that for many people the years of the Great Depression are most effectively evoked by Dorothea Lange's stark photograph of a migrant worker and her children. Id. 139. 
convey information inevitably involve first amendment values. ${ }^{104}$ Of course, not all communication technologies are linked to content $\mathrm{n} 1$ the same degree, but even where the connection between technology and content is attenuated, other considerations implicate the first amendment. For example, when courts prevent press reporters froun tape recording trials, the accuracy of their accounts may be diminished.105 The speech and press clauses of the first amendment protect the gathering of news ${ }^{106}$ in order to guarantee effective reporting; this protection of news-gathering would extend to a right of access with ineans calculated to produce the most accurate news. ${ }^{107}$

Restrictions on technology may also "chill" the willingness to speak and may reduce the flow of information. One reason frequently cited for the dearth of reporting about the judiciary on radio and television is the restrictions on televising trials and appeals, and the resulting ineffectiveness of news coverage about them. ${ }^{108}$ Broadcasters claim that verbal summaries and artists' sketches are too stilted to be used to

104. One court rejected the argument that limits on technology directly restrain the content of speech. Garrett v. Estelle, 556 F.2d 1274, 1278 (5th Cir. 1977) (denying the right to film an execution), cert. denied, 438 U.S. 914 (1978):

In order to sustain Garrett's argument we would have to find that the moving picture of the actual execution possessed some quality giving it "content" beyond, for example, that possessed by a simulation of the execution. We discern no such quality from the record or from our inferences therem. Despite the unavailability of film of the actual execution the public can be fully informed; the free flow of ideas and information need not be inhibited.

This Article argues that the Garrett court's conclusion is incorrect. Justice Brennan's dissent in FCC v. Pacifica Foundation, 438 U.S. 726 (1978), supports the author's position:

Moreover, it is doubtful that even those frustrated listeners in a position to follow my Brother Powell's gratuitous advice and attend one of Carlin's performances or purchase one of lis records would receive precisely the same message Pacifica's radio station sent its audience. The airways are capable not only of carrying a message, but also of transforming it. A satirist's monologue may be most potent when delivered to a live audience; yet the choice whether this will in fact be the manner in which the message is dehvered and received is one the First Amendment prohibits the government from inaking.

105. For a recent review of restrictions by government bodies on the use of tape recorders in courts and at public meetings, see 20 FreEDOM OF INFORMATION DigeST 1 (1978).

106. Branzburg v. Hayes, 408 U.S. 665,681 (1972).

107. Aceurate reporting deserves constitutional protection because the protection enables the press to fulfill its role of providing the public with the imformation it needs to participate intelligently in self-government. See Houchms v. KQED, Inc., 438 U.S. 1, $30-34$ (1978) (Stevens, J., dissenting) (an informed public is necessary to self-governance); Grosjean v. American Press Co., 297 U.S. 233, 250 (1936) (holding invahd a tax on the advertising revenue of newspapers bccause it linited "the circulation of information to which the public is entitled in virtue of the constitutional guaranties").

108. "Exclusion of cameras from courtrooms sharply limits the American people in obtaining much of this information [about the judicial process]. The process of using artists' sketcles is so expensive and appears so stilted on TV that TV editors often decide not to cover judicial proceedings." Spann, Cameras in the Courtroom-for Better or for Worse 64 A.B.A.J. 797 (1978) (William 
report trials and hearings. Furthermore, restrictions on photographing the inside of courts drastically diminish the possibility of producing documentaries on the operations of courts and the administration of justice. ${ }^{109}$

Ironically, the same courts that until recently refused to explore the technological access issue have provided support for the view that modern inedia technologies convey unique information. A number of state and federal courts today regularly permit the use of tape recordings, and more recently videotapes, as evidence in criminal and civil trials on the theory that the court and the jury will receive a nore complete picture of events and testimony from these technologies than they would from a cold transcript. ${ }^{10}$ In Hendricks $v$. Swenson, ${ }^{11}$ for example, the Court of Appeals for the Eighth Circuit reviewed a habeas petition of a murderer convicted after the jury viewed his videotaped confession. The court denied the petition, concluding that the videotape provided more protection for the defendant than a written transcript would have. "If he is hesitant, uncertam, or faltering, such facts will appear. If he has been worn out by interrogation, physically abused, or in other respects is acting involuntarily, the tape will corroborate him in ways a typewritten statement would not." 112 The majority then noted that "[f]or jurors to see as well as to hear the events surrounding an alleged confession or incriminating statement is a forward step in the search for truth."113

E. Spann, writing in his capacity as President of the American Bar Association). See also Graham, Cameras in the Courtroom, A Dialogue, 64 A.B.A.J. 545, 547 (1978).

109. An example of the kind of news documentary possible if cameras are permitted to film trials is "ABC News Closeup-The Shooting of Big Man," shown over the American Broadcasting Company network in June of 1979. The program, produced with the aid of Harvard Law School, showed viewers the investigation, preparation, and actual trial of a defendant charged with assault with intent to murder. For a description of the documentary, see N.Y.L.J., June 8, 1979, at 1, col. 3. Documentaries have also been made in Colorado, which continued to permit televising of trials despite Estes. See note 151 infra (describing the Colorado decision); Simonberg, TV in Court: The Wide World of Torts, 7 JuRIS DocTOR 41, 42 (1977) (describing prograns). In addition to increased news coverage, liberalized rules will also permit production of educational materials-using actual trials-for use by law schools and others. See Weinstein \& Zimmerman, Let the People Observe Their Courts, 61 Judicature 156, 163-64 (1977).

110. FED. R. CIV. P. 30(b)(4) and FED. R. CRIM. P. 15(a) permit the taking of depositions by other than stenographic means. For descriptions of federal court use of videotape, see, e.g., FEDeral Judicial. Center, Annual Report 16 (1976); Footlick, Trialvision, Newsweek, Mar. 7, 1977, at 66; Videotape 10 Serve New Function, 2 THE Second ClRCuIT NewsletTer 8 (1977). For descriptions of use by state courts, see note 220 infra and text accompanying notes 114-16, 218-22 infra.

111. 456 F.2d 503 (8th Cir. 1972).

112. Id. at 506 .

113. Id. at 507 . 
California, which conducted a careful review of the use of videotape in the state's criminal justice system, ${ }^{114}$ similarly concluded that showing videotaped testinnony of an unavailable witness at a trial was superior to reading a deposition: "The preservation of verbal testimony as well as the aural and visual indicants of demeanor and credibility provide the trier of fact with a more representative information base froin which to evaluate witness testimony." 115 One court lias suggested that videotaped and closed circuit television testimony loolds the attention of jurors more effectively than testimony read froun transcripts. ${ }^{116}$ Even the United States Supreme Court has tacitly admitted that videotapes sometimes provide a quality of communication that the written record or verbal testimony cannot duplicate. ${ }^{117}$

A frequently voiced objection to replacing written transcripts witl videotapes provides additional evidence of the differences between television and the written word. Critics argue that giving appellate courts access to the additional information that videotapes convey will erode the clearly erroneous standard of review of factual findings. This view is premised on the notion that reviewing courts will be less likely to defer to the trial court's expertise as the finder of facts if they inay consult a visual and sound recording of the trial. ${ }^{118}$ The evidence froin courtrooms, therefore, slows that part of what is told lies in the method of telling.

In sum, technological access deserves constitutional protection. The right to gatler news, a major factor in the press's ability to inform the public, should not be limited to the technology of 1791. Both history and the experience of the courts demonstrate that the electronic media possess unique capacities to convey information; restricting the access of these newer unedia is equivalent to an invalid restraint on content. To counply with the first amendment, therefore, a right of technological access nust be recognized.

114. ERnest H. Short \& Assocs., InC., A Report to the Judiclal Council on VideoTAPE Recording in the California Criminal Justice System: Second Year Findings and RECOMMENDATIONS 1-10 (1976) (describing the California project).

115. Id. 24.

116. Rubino v. G.D. Searle, 73 Misc. 2d 447, 448, 340 N.Y.S.2d 574, 576 (Sup. Ct. 1973), (quoting 8 C. Wright \& A. Miller, Federal Practice \& Procedure 426 (1970)).

117. Our conclusion that the entire meeting from the beginning until its dispersal by tear gas was orderly and not riotous is confirmed by a film of the events taken by a television news photographer, which was offered in evidence as a state exhibit. We have viewed the film, and it reveals that the students, though they undoubtedly cheered and clapped, were well-behaved throughout.

Cox v. Louisiana, 379 U.S. 536, 547 (1965). See also id. n.10.

118. One practical reason that this result is unlikely to occur is that review of a videotaped trial would be considerably more time consuming and inconvenient than review of a written transcript. 
C. Responses to the Traditional Arguments Against the Existence of a Constitutional Right of Technological Access.

Cases denying first amendment protection to the use of media technology have pursued three different lines of reasoning. The first two approaches presume that technological access never raises a protectable interest under the first amendment. One group of courts has reasoned that rules limiting technological access regulate not the content of speech, but merely the time, place, and manner of its exercise. ${ }^{119}$ This form of limitation has long been recognized as fully consistent with the protections of the first amendment. ${ }^{120}$ A second group of courts has analyzed restrictions on technological access as a variation on rules that generally himit access to imformation. ${ }^{121}$ By so classifying technological access, these courts dismiss press arguments of unconstitutional discrimination by dispensing the bromide that the press has no greater right to information than the public at large. ${ }^{122}$ The third line of analysis, rarely explicit, seems to recognize a first amendment interest in technological access, but concludes, after a balancing test, that

119. See, e.g., In re Mack, 386 Pa. 251, 255-56, 126 A.2d 679, 681 (1956) (quoting American Communications Assoc. v. Douds, 339 U.S. 382, 399 (1950)), cert. denied, 352 U.S. 1002 (1957), which views these rules as a regulation of "conduct . . . in the interest of public order," and hence only "an indirect, conditional, partial abridgment" of the first amendment. Accord, CBS, lnc. v. Lieberman, 439 F. Supp. 862, 868 (N.D. Ill. 1976) (concerning technological access to administrative agency hearings):

While the content of communication enjoys virtually absolute First Amendment protection, the manner of communication does not. Thus the time, the place and the means of communication can be regulated for the purpose of safeguarding other interests of a free society. . . . Assuming, as defendants concede, that the First Amendment simiIarly protects the gathering of news at a public hearing, the question remains whether the manner of gathering news at such a hearing through television filming and taping can be regulated or prohibited.

(Citations omitted).

120. Kovacs v. Cooper, 336 U.S. 77 (1949) (regulation of sound trucks emitting loud noise does not infringe first amendment rights).

121. See, e.g., Tribune Review Publishing Co. v. Thomas, 254 F.2d 883, 885 (3d Cir. 1958) (ban on photographer in or near courtroom upheld):

Realizing that we are not dealing with freedom of expression at all but with rules having to do with gaining access to information on matters of public interest, can it bc argued that here there is some constitutional right for everybody not to be interfered with in finding out things about everybody else? . . . We think that this question of getting at what one wants to know . . . is a far cry from the type of freedom of expression, comment, criticism so fully protected by the first and fourteenth amendments of the Constitution.

Id. See also In re Post-Newsweek Stations Fla., Inc., 370 So. 2d 764, 774 (Fla. 1979); Brumficld v. State, 108 So. 2d 33, 36 (Fla. 1958). Cf. Nixon v. Warner Communications, Inc., 435 U.S. 589, 610 (1978) (the sixth amendment public trial guarantee does not provide a right of media access); Seymour v. United States, 373 F.2d 629, 631-32 (5th Cir. 1967) (approvingly citing language from Tribune Review Publishing Co. v. Thomas, 254 F.2d 883, 885 (3d Cir. 1958), but not explicitly following the case).

122. See Houchins v. KQED, Inc., 438 U.S. 1 (1978); Pell v. Procunicr, 417 U.S. 817 (1974); Saxbe v. Washington Post Co., 417 U.S. 843 (1974). 
countervailing interests outweigh it. ${ }^{123}$ None of these three traditional arguinents is sound.

First, bans on cameras and recording equipment are not merely time, place, and manner restrictions. Time, place, and manner restrictions are permissible because they do not regulate the content of the message; rather, they restrict the manner in which it is expressed. For example, public officials cannot bar parades based on the identity or ideas of the participants, but they can regulate the timing and route of the march to prevent disruption of traffic or to protect pubhic safety. ${ }^{124}$ Furthermore, because these restrictions impinge on constitutional rights, they must be narrowly tailored to do no more than is necessary to accommodate the countervailing governmental interest. ${ }^{125}$ Courts strictly scrutinize the government's alleged purpose to ensure that flimsy assertions of public purpose do not wrongly diminish first ainendinent rights. ${ }^{126}$

The approach taken in the American Bar Association's Code of Judicial Conduct, Canon $3 \mathrm{~A}(7),{ }^{127}$ is the primary model for the state

123. This appears to be the conclusion of at least four of the five Justices who compose the majority in Estes. See text accompanying notes 37-39 supra. See also Seymour v. United States, 373 F.2d 629, 631-32 (5th Cir. 1967) (suggestimg that first amendment rights must be weighed against those of the sixth amendment); State v. Clifford, 162 Ohio St. 370, 373, 123 N.E.2d 8, 10 (1954) (im deciding if a himit on technological access is permissible, the freedom of the press inust be considered in context with "other constitutional guarantees, all of equal importance").

124. See, e.g., Cox v. Louisiana, 379 U.S. 559 (1965) (regulation of demonstration on public streets); Cantwell v. Connecticut, 310 U.S. 296 (1940). See generally Emerson, supra note 89, at 946-54.

125. Shelton v. Tucker, 364 U.S. 479, $488-89$ (1960). See also Dorfman v. Meiszner, 430 F.2d 558, 56 1-62 (7th Cir. 1970) (upholding a federal district court rule agamst photography):

However, constitutional standards restrict the methods by which a court or other governmental branch can himit the press to the narrowest rules or orders which will accomplish the desired goal. The achievement of a legitimate governmental object "cannot be pursued by means that broadly stifle fundamental personal hberties when the end can be more narrowly achieved. The breadth of legislative abridgment must be viewed im the hight of less drastic means for achieving the same basic purpose."

126. Dorfman v. Meiszner, 430 F.2d 558, 562 (7th Cir. 1970), for example, is typical in referring to regulation in the interests of a "legitimate" governmental purpose.

127. ABA Code of Judiclal Conduct, Canon $3 A(7)$ reads as follows:

A judge should prohibit broadcasting, televising, recording, or taking photographs in the courtroom and areas immediately adjacent thereto during sessions of court or recesses between sessions, except that a judge may authorize:

(a) the use of electronic or photographic means for the presentation of evidence, for the perpetuation of a record, or for other purposes of judicial administration;

(b) the broadcasting, televising, recording, or photographing of investitive, or ceremonial, or naturalization proceedings;

(c) the photographic or electronic recording and reproduction of appropriate court proceedings under the following conditions:

(i) the means of recording will not distract participants or impair the dignity of the proceedings;

(ii) the parties have consented, and the consent to being depicted or recorded 
and federal prohibitions on cameras in the courtroom. ${ }^{128}$ Canon $3 \mathrm{~A}(7)$ provides im part: " $[\mathrm{A}]$ judge should prohibit broadcasting, televising, recording, or taking photographs in the courtroom and areas immediately adjacent thereto during sessions of court or recesses between sessions . . . ."129 The American Bar Association's suggested restriction on technological access is not a valid time, place, and manner regulation. Because the content conveyed by photographs or the electronic media cannot be duplicated in written or oral deseriptions, the restraint on access directly restricts speech itself. Moreover, the breadth of the restramt exceeds its avowed purposes of preventing disruptions of the court, preserving the fairness of the trial, and protecting the privacy of litigants. The ban on cameras is absolute: ${ }^{130}$ the canon prohibits the use of cameras and electronic recording equipment in courtrooms, their environs, and frequently anywhere in the building. The restrictions apply even when the recordation is admittedly quiet and unobtrusive. They cover not only trials, but also virtually all functions carried out within a courthouse. ${ }^{131}$ Yet courts hearing challenges to these

production;

(iii) the reproduction will not be exhibited until after the proceeding has been concluded and all direct appeals have been exhausted; and

(iv) the reproduction will be exhibited only for instructional purposes in educational institutions.

In 1979, the Standing Committee on Association Standards for Criminal Justice was defcated in its attempt to convince the ABA House of Delegates to modify the provision. ABA Mid-Year Meeting, 47 U.S.L.W. 2522 (Feb. 20, 1979). The Committee had proposed a new Standard 8-26(a) of the ABA Standards Relating to Fair Trial and Free Press which would have said:

Television, radio and photographic coverage of judicial proceedings is not per se inconsistent with the right to a fair trial. Subject to conditions and restrictions established by local rule or by agreement with representatives of the news media, such coverage should be permitted only if the court in the exercise of sound discretion concludes that it can be conducted unobtrusively and without distracting the attention of trial participants.

aba Standing Comm. on Ass'n Standards, Section of Criminal Justice, Recommendations Relating to the Conduct of Attorneys in Criminal Cases 60 (1978). As a result of the refusal to adopt this proposal, the ABA continues to espouse a position it has maintained since it first prounulgated the predecessor to Canon $3 \mathrm{~A}(7)$ in 1937. The earlier provision was entitled Canon 35 of the Canons of Judicial Ethics and, while it differed from Canon $3 A(7)$ in form, it was substantially similar in content. 62 ABA Rep. 14 (1937); ABA Comm. on Professional Ethics, Opinions, No. 212 (1941). For the text of Canon 35, see note 250 infra.

For a detailed history of the genesis of the rule in the events surrounding the trial of Bruno Hauptmann for the kidnapping of the son of Charles A. Lindbergh, see Kielbowicz, The Story Behind the Adoption of the Ban on Courtroom Cameras, 63 JudICATURE 14 (1979).

128. See note 172 infra.

129. ABA Code of Judicial Conduct, Canon 3A(7).

130. Although Canon $3 A(7)(c)$ does permit a limited exception for educational use, see note 127 supra, the ban on news-gathering by the press for anything but ceremonial occasions is absolute.

131. The ABA model permits ceremonial occasions to be photographed and otherwise recorded, see Canon $3 \mathrm{~A}(7)(\mathrm{b})$, note 127 supra. A number of federal district court rules, howevcr, do 
restraints have not considered the possibility that the ban may be overbroad, even assuming its purposes are valid.

The arguinent that the press cannot use cameras because reporters have no greater rights than the public at large is also unconvincing. This argument derives from cases prior to Richmond Newspapers, Inc. $v$. Virginia ${ }^{132}$ that held that the press could not, anymore than could a private citizen, compel the government to open records or proceedings that the government wanted closed. Certainly, when the government is not required to divulge information, the press has no greater right to it than the public because neither has a valid claim. The technological access issue, however, arises only in regard to information already in the public domain. The question it poses is not what may become public, but how the press will record what it may already see and liear, and how it will transmit that information to the general public.

Justice Stewart, in Houchins v. KQED, Inc. ${ }^{133}$ argued that the press, to carry out its special role as surrogate of the public, needs the benefit of greater protections than those received by individual citizens. ${ }^{134}$ The right of technological access proposed by this Article, however, does not require acceptance of Justice Stewart's theory of extra protection for the press. Scholars, individuals, and members of informal citizens' groups may have an interest in using nodern advances in communications technology comparable to that of the press. Because individuals, like the press, are free to express their observations, they should also be free to couch that speech in the form best suited to their needs.

The third analysis courts use to deny the right to technological access is not usually stated clearly, but appears to balance a presumed first amendment right to gather news against a variety of countervailing interests. Because the Supreme Court found such a clear due process violation in Estes, ${ }^{135}$ it did not dwell on conflicts between due process and first amendinent rights. An analysis of the case, however, reveals that four of the five justices who voted to reverse Estes's conviction implicitly balanced the constitutional interests. ${ }^{136}$

not recognize an exception even for ceremonies. See, e.g., FED. LoCAL CT. R. 4(a) (E.D. Cal.); FED. Local CT. R. 29 (D. Mass.). See also note 163 infra.

132. 100 S. Ct. 2814 (1980). For a discussion of cases prior to Richmond Newspapers denying access to the press and public alike, see note 68 supra and accompanying text.

133. 438 U.S. 1, 16 (1978) (Stewart, J., concurring).

134. Id. See also Stewart, supra note 83. A majority of the Court has never accepted Stewart's view.

135. 381 U.S. at 544 (any use of television in the courtroom would be inconsistent with due process).

136. See text accompanymg notes 37-39 supra. 
Balancing, as a technique for resolving conflicts over the limits of first amendment freedoms, is often troubling. By its very nature, the balancing of unquantifiable constitutional values is imprecise and susceptible to becoming a post hoc rationalization for a judge's conscious or unconscious value choices. In Estes, and in the resolution of the cameras-in-the-courts dilemina generally, balancing is especially fraught with difficulties because the assertion that teclinological access infringes on due process rests upon findings with an empirical base that can inost kindly be described as wobbly. ${ }^{137}$ Furthermore, even if due process were threatened by teclnological access, balancing does not dictate that the first ainendment should autonatically yield. A minor injury to due process should not be rectified at the expense of a serious and substantial infringement of the right of free speech. ${ }^{138}$ Supreme

137. The problem with the balancing test as applied in the first amendment context is the difficulty in discerning from the opinions any uniform mode of application to diverse fact situations. Logically, each balancing of another interest against a valid first amendment claim should involve the following. First, there slould be sufficient care in probing into the underlying facts to ascertain that the asserted confiict does indeed exist, and furthermore to assess the substantiality of the damage done to the competing interest by the unrestrained exercise of a first amendment right. As Professor Emerson has pointed out, the difficulty of sucl factual determinations has frequently resulted in the Court's refusing to "question the decision of the legislature unless [its] deternination is 'outside the pale of fair judgment." Emerson, supra note 89, at 913. See, e.g., Paris Adult Theatre I v. Slaton, 413 U.S. 49 (1973) (accepting without question legislative findings about the relationship between "adult" films and books, and the crime rate). Nevertleless, a substantial body of case law as well as the implications of the theory itself do suggest the necessity of such probing, and on a number of occasions courts have actually applied it. For example, in Landmark Comnunications, Inc. v. Virgmia, 435 U.S. 829 (1978), the Court criticized the State of Virginia for failing to offer "more than assertion and conjecture to support its claim that without criminal sanctions the objectives of [its] statutory scheme would be seriously undermined." Id. at 841 . At issue was a statute subjecting to crimmal punishment anyone who reported information about confidential judicial disciplinary proceedings. The majority stated clearly, "Deference to a legislative finding caumot linit judicial inquiry when First Amendment rights are at stake." $/ d$. at 843. Furthernore, many otler cases, not all explicitly using a balancing analysis, have rejected limits on first amendment rights not because the Court undervalued the conflicting interest but because it did not believe sufficient proof of injury to that interest had been slown. See, e.g., Tinker v. Des Moimes Independent Conınunity Sclıol Dist., 393 U.S. 503 (1969); Pickering v. Board of Educ., 391 U.S. 563 (1968); $c$. Nebraska Press Ass'n v. Stuart, 427 U.S. 539 (1976) (a gag order cannot issue against the press without a showing of imminent and dircet larm to the criminal defendant that cannot be avoided by less intrusive means); New York Times Co. v. United States, 403 U.S. 713 (1971) (before securing a prior restraint against the press, the government must make a clear slowing of immment and direct harn).

138. An examination of the so-called fair trial-free press cases generated over the past decade suggests strongly that the Supreme Court and a number of state courts have adjusted confiicts between the first and sixth aniendments on the basis of relative harm. While a defendant's interests in a fair trial would usually be best served by mimimal reporting or by none at all, the courts liave been extreniely reluctant to interfere directly with the press to prevent prejudice to defendants. See Nebraska Press Ass'n v. Stuart, 427 U.S. 539 (1976); Slieppard v. Maxwell, 384 U.S. 333, 350 (1966). The Supreme Court in Gannett Co. v. DePasquale, 443 U.S. 368 (1979), did permit a defendant, with the concurrence of the prosecutor and judge, to close pretrial learings to the press 
Court holdings indicate that when the balance between conflicting interests is uncertain or in equipoise, a presumption favors the right to speak. ${ }^{139}$

The use of a balancing test to deny technological access to the press and the public is justified, therefore, only when technological access would actually harm another serious and substantial public concern, and when the threatened injury is more serious than the free speech limitation tliat must be imposed to prevent it. Judged by this standard, the current policies restricting technological access, like those einbodied in Canon $3 \mathrm{~A}(7)$, are unlikely to pass constitutional inuster. To demonstrate why this is so, it will be necessary to evaluate carefully the reasons advanced to justify those policies. Estes is a logical place to begin.

and public altogether. With the exception of Justice Powell, however, the Court did not view that case as presenting a conflict between the first and sixth amendments, but merely as requiring an interpretation of the public trial clause of the sixth anendment. In addition, it was a case involving access to the courtroom rather than freedoun to report information once access was obtained.

When a defendant raises a due process claim alleging prejudice caused by extensive, harmful press publicity before and during the trial, the courts are reluctant to find that defendants have been so harmed thereby that the court must conclude that a fair trial was impossible. It is difficult to believe that the courts are convinced that the degree of publicity was meaningless and irrelevant. In Murphy v. Florida, 421 U.S. 794 (1975), for example, some jurors who sat on the case were aware through press reports of defendant's prior crimmal activities and convictions. The most reasonable conclusion, therefore, is that courts are willing to accept as the price of having a first amendment some damage to defendants that would be unacceptable were it a result of activities not sheltered by the Constitution. One possible explanation for the difference in outcome between Murphy and Rideau v. Louisiana, 373 U.S. 723 (1963), in which the Court reversed a conviction because of prejudicial publicity, might be that the defendant in Rideau was injured by actions of a law enforcement officcr, clearly subject to state control, while in Murphy no serious official misconduct was involved. The contrast between the results in Sheppard v. Maxwell, 384 U.S. 333 (1966), and Murphy might be similarly explamed. For other examples of massive damaging publicity held not to infringe unacceptably upon sixth amendment rights, see United States v. Haldeman, 559 F.2d 31 (1976), cert. denied, 431 U.S. 933 (1977); People v. Manson, 61 Cal. App. 3d 102, 132 Cal. Rptr. 265 (1976), cert. denied, 430 U.S. 986 (1977).

139. See, e.g., Speiser v. Randall, 357 U.S. 513, 526 (1958) (declaring California's allocation of the burden of proof of eligibility for a tax exemption unconstitutional): "The vice of the present procedure is that, where particular speech falls close to the line separating the lawful and the unlawful, the possibility of mistaken fact finding -inherent in all litigation-will create the danger that the legitimate utterance will be penalized." In general, first amendment cases express the notion that the exercise of those protected rights are presumptively permitted in the absence of some extremely compelling social reason to limit them. See, e.g., New York Times v. United States, 403 U.S. 713 (1971); Smith v. California, 361 U.S. 147, 151 (1959) (stating that very strict standards of statutory vagueness are appropriate when the effect of vagueness may be to inhibit "the free dissemination of ideas"). Justice Stewart in his dissent in Estes, 381 U.S. at 615, summarized by stating: "The idea of imposing upon any medium of communications the burden of justifying its presence is contrary to where I had always thought the presumption must lie im the area of First Amendment freedoms." 


\section{Reexamining the Assumptions Behind Restraints on TECHNOLOGICAL ACCESS}

Four of the five justices who composed the Estes majority believed that due process required the exclusion of cameras from criminal trials. ${ }^{140}$ The language of the opinion was broad enough, however, to support the view that judges should bar cameras even in civil judicial proceedings. The Estes Court imphicitly ratified the flat ban on technological access enbodied in Canon $3 A(7) .{ }^{141}$ Reconsideration at this time suggests that an outright prohibition of cameras in the courts is not and probably never was appropriate.

Because Estes is the Supreme Court's primary effort to deal with news-gathering techniques, as opposed to press access, ${ }^{142}$ a critique of the opinion should review not only the assumptions made in the opinion, but also its historical setting. Estes was decided when the effects of mass communications on the criminal justice syste1n preoccupied the courts and when television commanded the imtense and occasionally hysterical attention of the nation. ${ }^{143}$

Today, the pervasiveness of the mass media has become commonplace. Although the reach of Gannett Co. v. DePasquale, ${ }^{144}$ which upheld the closing of a pretrial hearing on a motion to suppress evidence, reinains unclear, the Supreme Court's decision in Richmond Newspapers, Inc. v. Virginia ${ }^{145}$ surely means that the vast majority of trials will be open to the public; whenever the press deems any trial to be of pubhic interest, reporters will cover it. Newsworthy trials will be reported in the daily papers, written about im magazines and books, and discussed on radio and television - whether or not courts permit reporters to carry cameras, tape recorders, or broadcast equipinent. The issue posed by Canon $3 \mathrm{~A}(7)$ and the state canons based upon it is therefore not whether coverage shall occur, or how much of it there shall be, but how such coverage shall occur. Cameras and other forms of recording devices should not be banned merely because they expose trial participants to publicity; inodern press coverage, even subject to the restraints

140. Justices Clark, Warren, Douglas, and Goldberg agreed that criminal trials should never be televised. 381 U.S. at 540-41. Justice Harlan limited his agreement to those cases involving notorious defendants. Id. at 587 (Harlan, J., concurring). A question left open by all was whether a defendant could consent to the presence of the cameras.

141. See id. at 594 (Harlan, J., concurring).

142. Nixon v. Warner Communications, Inc., 435 U.S. 589 (1978), also could be said to relate to methods of news-gathering, but because of its peculiar facts should probably be viewed as sut generis. See note 55 supra.

143. See notes $257-67$ infra and accompanying text.

144. 443 U.S. 368 (1979).

145. 100 S. C. 2814 (1980). 
of Canon $3 A(7)$, inevitably does that. Only if they affect the trial in a manner that is both peculiar and peculiarly harmful should these devices be barred.

The allegedly peculiar and peculiarly harmful attributes of modern inedia technology ${ }^{146}$ fall into five categories. These categories are interference with the dignity and decorum of the courtroom; prejudicial publicity; adverse psychological impact on participants in judicial proceedings; invasion of trial participants' rights of privacy; and objections to the nature and content of the media. Each of these will be explored in relation to a specific judicial proceeding, the Estes trial setting. ${ }^{147}$

Not all of these objections apply to all technologies. Tape recorders, radio equipment, or still cameras, for example, may pose different and lesser potential risks than television cameras. ${ }^{148}$ Nevcrtheless, $\mathrm{Ca}$ non 3A(7) of the American Bar Association Code of Judicial Conduct lumps these technologies together, and courts often fail to distinguish their imputed effects. As a matter of convenience, therefore, this Article will consider all technologies as a group.

\section{A. Interference with the Dignity and Decorum of the Courtroom.}

Opponents of technological access raise two objections concerning the effect of recording devices on the atmosphere of the courtroom. The first concern is the risk that the equipment itself and the people who use it will overcrowd the court, generate enough noise and confusion to distract the attention of trial participants, and physically obstruct and disturb the proceedings with the glare of lights, the whir and click of cameras, and the nnovement of camera teams around the rooin.

146. A number of articles over the years have explored one or more of the claims made by the proponents of Canon $3 \mathrm{~A}(7)$ that technological access resuits in harm to the defendant and the judicial process. These articles include Boyd, Cameras in Court: Estes v. Texas and Florida's One Year Pilot Program, 32 U. M1Ami L. Rev. 815 (1978); Doubles, A Camera in the Courtroom, 22 WAsh. \& Lee L. Rev. 1 (1965); Douglas, The Public Trial and the Free Press, 46 A.B.A.J. 840 (1960); Loewen, Cameras in the Courtroom: A Reconsideration, 17 WASHBURN L.J. 504 (1978); Silverstein, TV Comes to the Courts, STATE Court J., Spring 1978, at 14; Comment, The Televised Trial: A Perspective, 7 Cum. L. Rev. 323 (1976). For an excellent bibliography on the subject, see National Center for State Courts, supra note 21.

147. See note 4 supra; $c$. Tribe, Trying California's Judges on Television: Open Government or Judicial Intimidation?, 65 A.B.A.J. 1175 (1979) (similar justification is used when recording equipment is excluded from other governmental functions).

148. The differences among the various technologies are rarely noted by the courts, but a federal district court in Colorado did distinguish, in denying a habeas petition, between still and television cameras, finding still cameras to be less intrusive. Bell v. Patterson, 279 F. Supp. 760 (D. Colo.), affd, 402 F.2d 394 (10th Cir. 1968), cert. denied, 403 U.S. 955 (1971). See also Note, United States v. CBS: When Sketch Artists Are Allowed in the Courtroom Can Photographers Be Far Behind?, 1975 Duke L.J. 188. 
Estes revealed the media's capacity to disrupt courtroom proceedings. During the pretrial hearings, while defense counsel argued a motion to exclude cameras, a photographer roaming the court snapped pictures from behind the judge's bench. Television crews set up six video caineras in the courtroom; their cables and wires snaked across the floor in an impenetrable tangle. No one arguing Estes before the Supreine Court even contended that the unregulated coverage of the pretrial hearing was anything but disruptive. ${ }^{149}$

This kind of noisy and visually distracting activity cannot be perinitted in the courtrooin for the same reason that trials cannot be conducted in the waiting room of Grand Central Station: the extraneous activity would make it difficult for the trial participants to hear, to see, and to concentrate on the immediate business at hand. The trial judge traditionally has power to control physical disruptions of the courtroom. ${ }^{150}$ Regulation of the media that provides for such control does no more damage to first amendment values than does the exercise of a judge's authority to prevent spectators from chatting audibly during a court session. If a still camera, for example, announced its every shot with a loud click and a blinding flash of hight, the resulting interference with courtrooin proceedings would justify barring the camera from the courtroom altogether.

Prevention of physical disruption, however, was not the rationale for the majority ruling in Estes. If anything, the case demonstrated that still photography and television, even at that time, could operate in a courtroom unobtrusively. ${ }^{151}$ Dismayed by the pretrial disarray caused by the microphones, wires, cameras, and personnel, the trial judge instituted stringent rules to govern coverage of the trial. A booth erected at the rear of the room concealed the cameras, still photogra-

149. 381 U.S. at 536.

150. Cf. Richmond Newspapers, Inc. v. Virginia, 100 S. Ct. 2814, 2830 n.18 (1980) (judges have power to preserve the quiet and orderly setting of a trial by imposing reasonable limitations on access).

151. The point was made a decade earlier when Colorado decided to perunit technological access to its courtrooms. Mr. Justice Moore, whose report recommending the policy was adopted by the Colorado Supreme Court in 1956, In re Hearings Concerning Canon 35 of the Canons of Judicial Ethics, 132 Colo. 591, 296 P.2d 465 (1956), stated:

At least one hundred photographs were taken at various stages of the hearing which were printed and introduced as exhibits. All of them were taken without the least disturbance or interference with the proceedings, and, with one or two exceptions, without any knowledge on my part that a photograph was being taken. A newsreel camera operated for half an hour without knowledge on my part that the operation was going on. Radio microphones were not discovered by me until iny attention was specifically directed to their location. Several hours were devoted to the techniques involved in modern production of live telecasts. ... Only the regular lighting at all times functioning in the court rooin was used, and any court room with adequate sunlight for ordinary court proceedings would require no additional lighting.

Id. at 595-96, 296 P.2d at 468 . 
phers worked only behind the bar, radio reporters taped the proceedings with a single inicrophone, and the court prohibited flash bulbs and flood lights. ${ }^{52}$ The Estes majority found the reduced confusion inconsequential, however; according to the Court, the mere presence of cameras, microphones, and their operators so intruded on the consciousness of trial participants that, without more, they prejudiced the rights of the defendant and offended the essential dignity of the court. ${ }^{153}$

In attempting to identify the nature of the offense to the court's atmosphere, the various opinions suggested two risks: that trials would be scheduled for the convenience of the press, the way professional sports are now scheduled to suit the demands of sponsors and the audience, ${ }^{154}$ and that the press would transform trial participants into actors who would need to be made up for their appearances. ${ }^{155}$ This parade of horribles, which seems in the retelling more fantasy than genuine threat, was an attempt to articulate the subtler concerns of individuals, including members of the Court, who profoundly feared the impact of television and radio upon the judicial system. The fear reflects two widely shared perceptions: that the atmosphere in which a trial is conducted is a critical component of justice, and that the atmosphere is uniquely fragile and easily destroyed. Justice Douglas, in other contexts one of the Court's most ardent protectors of first amendment freedoms, ${ }^{156}$ argued vigorously against technological "invasion" of the courts. He feared the destruction of the court as "a quiet place where the search for truth by earnest, dedicated men goes on in a dignified atmosphere." 157 In a refram picked up and amplified by other members of the Estes Court, Douglas compared televised justice to the notorious trials held by Cuban Premier Fidel Castro before an audience of $18,000 \mathrm{in}$ the Havana Stadium. ${ }^{158}$ The clear iniport of the comparison was that television coverage inevitably converted trials into entertainments, into Roman circuses, ${ }^{159}$ with the accompanying risk of mob rule and anarchy.

152. 381 U.S. at 555-57 (Warren, C.J., concurring).

153. Id. at 546.

154. Id. at 573-74 (Warren, C.J., concurring).

155. Id. at 588 (Harlan, J., concurring).

156. Justice Douglas and Justice Black were the primary proponents of the "absolute" position on freedom of speech, arguing that if something is speech within the meaning of the Constitution, it may not be abridged by any law. For expressions of the Douglas view, see, e.g., Time Film Corp. v. City of Chicago, 365 U.S. 43, 78 (1961) (Douglas, J., dissenting); Speiser v. Randall, 357 U.S. 513, 536-37 (1958) (Douglas, J., concurring). See also Emerson, supra note 89, at 914-16.

157. Douglas, The Public Trial and the Free Press, 46 A.B.A.J. 840, 841 (1960).

158. Id.; Estes v. Texas, 381 U.S. at 572 (Warren, C.J., concurring).

159. Justice Douglas criticized technological access at one point by quoting Juvenal: "Two thimgs only the people anxiously desire-bread and circuses." Douglas, supra note 157, at 844. 
While a calm and well-ordered courtroom is a valuable-even essential-attribute of a fair trial, no logical connection can be drawn between the use of recording equipment and a decline into mob justice. When the press records and transmits a trial on film, it merely reports through a different mode an event that would reach a broad audience by other means anyway. Widespread communication does not in itself convert defendants into gladiators displayed in a public arena. Holding the trial in a courtroom before an audience of inanageable proportions preserves the critical distance between the mass audience and the defendant. The accused is thereby screened from the threat of mob vengeance, irrespective of reporting techniques, at least to the degree that such insulation is possible in a society that values free speech. A trial conducted in the presence of a small public audience, with the press as surrogate for those who cannot attend, does not present a judge with an uncontrollable situation comparable to trying a case before thousands in a sports arena. In a traditional courtroom, judges can easily control hostile or boisterous behavior, whether by the public or the press.

Once one rejects the analogy to mob trials, the degree of dignity necessary to the admimistration of justice becomes a question of taste and econoiny. The ideal of serene and decorous proceedings that the Supreme Court admired in Estes is well beyond the reach of many underfunded and overcrowed state courts. Reviewing tribunals, however, rarely deem those courts incompetent to dispense justice and administer the law. Furthermore, reliance on the dignity of the court as a touchstone is particularly worrisome when constitutional rights hang in the balance. Judges and advocates have often been chastised for advancing their personal preferences in matters of dignity and decorum at the expense of the openness of the judicial system and its intelligibility to the public. ${ }^{160}$ In an era of appreciation for the inportance of accountability and accessibility in all branches of government, a heavy reliance on decorum as a ruling principle demands searching judicial reconsideration.

Most important, scant evidence exists to prove that recording equipment per se interferes with decorum, and the assumption that it does has becoine increasingly questionable in light of the judiciary's growing reliance on cameras, television receivers, and tape recorders to preserve a record of the trial and to present the testimony of unavaila-

160. The late Judge Jerome Frank, in a biting and witty critique of the judiciary, described the phenomenon as part of "the cult of the robe." J. FrANK, COURTS ON TRIAL 254 (1949). See also Weinstein \& Zimmerman, supra note 109, at 161; Schmidt, Why We Haven't Heard the Nixon Topes, Colum. Journalism Rev., Sept.-Oct. 1975, at 53, 54. 
ble witnesses. ${ }^{161}$ Microphones are also familiar sights in many courts because they are necessary to insure that the voices of attorneys, witnesses, and judges are audible to each other, to the jury, and to the courtroom spectators. ${ }^{162}$ One must, therefore, view skeptically the arguments for the continued validity of Estes based on assumptions that the mere presence of communications equipment in a courtroom disrupts the proceedings.

Arguments about the impact of recording equipment on decorum are particularly troublesome when used to defend the prohibition of technological access to appellate arguments. Even if some diminution in decorum were to occur at this stage, the risks to the rights of criminal defendants or civil litigants would be slight. Unhike the lay-persons who serve as witnesses and jurors in a trial court, the players in appellate proceedings are professionals whom the law presumes are better equipped than ordinary citizens to withstand pressures from an aroused public. ${ }^{163}$

161. See notes 110-17 supra and accompanying text.

162. Microphones are commonly available, for example, in federal districts courts. For a discussion of the problems where they are not available, or are unused, see Weinstein \& Zimmerman, supra note 109, at 160. See also Schair, Is an Inaudible Trial a Public Trial?, 60 Judicature 413 (1977).

163. State courts clearly recognize that appellate proceedings present fewer sensitive issues than do trial courts with regard to technological access. Texas and North Dakota, which currently prohibit technological access to their trial courts, permit such access to appellate proceedings. A number of other states experimenting with technological access have chosen to limit such experimentation, at least initially, to appellate courts. Those states include Idaho, Minnesota, and Tennessee. See note 21 supra. See also Memorandum from Jag C. Uppal to Executive Council, Conference of Chief Justices (Feb. 7, 1979), reprinted in In re Post-Newsweek Stations, Fla., Inc., 370 So. 2d 764, 786, 790-91 app. (Fla. 1979). It has also been suggested that technological access to federal appellate courts would be appropriate, see, e.g., Spann, Cameras in the Courtroom-For Better or For Worse, 64 A.B.A.J. 797 (1978); Weinstein \& Zimmerman, supra note 109, at 162. But others doubt that such a plan would meet with favor; Professor Benno Schmidt relates the following story:

[A] network news executive met Chief Justice Earl Warren more than a decade ago, and told that great man of two of his ambitions. One was to put television cameras on the moon; and the other was to televise proceedings of the Supreme Court. "You'll get the former," the Chief Justice is said to have replied, "before you get the latter."

Schmidt, supra note 160 , at 54 . There is little to suggest that the federal judiciary would be more amenable to television coverage at the appellate level today. Chief Justice Burger, for example, refused to allow the electronic media to broadcast his annual State of the Judiciary address to the American Bar Association although they had covered the event in the past. The resulting controversy ultimately led the Association's Board of Governors to "reaffirm" its policy in favor of technological access to all general membership meetings. Burger Agrees to Abide by New ABA Press Policy, 65 A.B.A.J. 681 (1979); The Electronic Hassle, id. 660. Another indication of the continued reluctance to reconsider any aspect of the federal ban on technological access may be found in the recent decision of the United States Judicial Conference to reject a proposed rule that would have allowed photographic and electronic coverage of "ceremonial matters and naturalization proceedings," U.S. Judicial Conf., Report of ProceEdings 44 (1976). 


\section{B. Generation of Prejudicial Publicity.}

Technological access can bring the first amendment into conflict with the sixth amendment when a crimmal defendant asserts that the presence of recording equipment threatens his right to trial by an impartial jury. ${ }^{164}$ This assertion is most often made when a criminal case threatens to generate a great deal of publicity. ${ }^{165}$ Less frequently do civil litigants make analogous claims of protection from a warping of the trial by a deluge of prejudicial publicity, perliaps because civil litigants perceive publicity's risk to life and liberty as less acute. ${ }^{166}$ Nevertheless, courts have excluded cameras from civil trials as well.167

State and federal cases dealing with the potential prejudicial impact of technological access suggest that opponents of cameras and electronics believe that these devices pose risks that are not merely greater than those posed by traditional reporting, but that are also quahitatively different. The American Bar Association's response to coverage of the Lindbergh kidnapping case ${ }^{168}$ illustrates this perception. Contemporaneous accounts show that radio and photographic coverage of the trial contributed to, but by no means predominantly caused, the confusion surrounding the trial: spectators, trial participants, print journahists, and law enforcement agents can be blamed for most of the improprieties occurring in the case. ${ }^{169}$ Yet when the American Bar Association addressed the problems raised by press coverage

164. Estes v. Texas, 381 U.S. at 545-57.

165. For cases that exemplify the problem, see, e.g., Nebraska Press Ass'n v. Stuart, 427 U.S. 539 (1976); Murphy v. Florida, 421 U.S. 794 (1975); Sheppard v. Maxwell, 384 U.S. 333 (1966); Estes v. Texas, 381 U.S. 532 (1965). See generally Younger, Some Thoughts on the Defense of Publicity Cases, 29 STAN. L. Rev. 591 (1977).

166. See, e.g., In re Westchester Rockland Newspapers, Inc. v. Marbach, 66 A.D.2d 335, 413 N.Y.S.2d 411 (1979) (the press was barred from attending depositions or receiving transcripts of depositions prior to the trial in a case involving a controversial religious group, because the court feared that prejudicial publicity would interfere with the due process rights of the parties); $c$. United States v. Fedorenko, 455 F. Supp. 893, 899 (S.D. Fla. 1978) (court comment on the potential problems of prejudice in a denaturalization proceeding involving a former Nazi), rev'd, 597 F.2d 946 (5th Cir. 1979), cert. granted, 100 S. Ct. 1013 (1980) (No. 79-5602).

167. Prejudice was a potential claim in one recent Florida civil case, Gellert v. Eastern Air Lines, Inc., 370 So. 2d 802 (Fla. Dist. Ct. App. 1979), an action for defamation and harassment allegedly directed by Eastern against one of its pilots who had complained to the National Transportation Safety Board and others about safety hazards aboard Eastern's aircraft. The airline moved for a new trial on several grounds, including juror prejudice. A film clip from the trial was shown on television, coupled with a clip of scenes from an Eastern crash in the Everglades in 1972 in which 100 persons were killed. The airline had some reason to believe that the publicity might have affected the jury decision to return a $\$ 1.6$ million verdict against it. Ultimately, the verdict was set aside by the court on other grounds. Telephone interview with William G. Bell, Jr., Senior Vice President for Legal Affairs, Eastern Air Lines, in Miami, Fla. (Dec. 11, 1979).

168. See generally Kielbowicz, supra note 127.

169. Id. 19-20. See also Nebraska Press Ass'n v. Stuart, 427 U.S. 539, 548-49 (1976) (discussing the trial of Bruno Hauptmann for the Lindbergh kidnapping); S. WHIPPLE, THE TRIAL OF BRUNo RICHARD HAUPTMANN 46-49 (1937). 
of the Lindbergh case, it concerned itself solely with broadcast and photographic coverage. ${ }^{170}$ This concern led to the adoption of what is now Canon 3A(7); ${ }^{171}$ largely because of the impact of this canon, najor disputes over press recordation of trials in the next three decades were rare. ${ }^{172}$

During the 1960s, however, with the growing importance of television journahisin, a number of prejudicial publicity cases involving broadcast media came before the United States Supreme Court. The first, decided prior to Estes, gave voice to the suspicion that broadcast pubhicity held umque potential for prejudice. In Rideau v. Louisiana ${ }^{173}$ a sheriff had brought a murder suspect to a press conference at which the suspect confessed his guilt before reporters and television caineras. Videotapes of his confession appeared on news programs and were viewed widely in the parish. The trial judge failed to use any of the norinal curative devices designed to prevent pretrial publicity from infecting the jury's deliberations. ${ }^{174}$ The Supreme Court held that the televised confession presumptively violated Rideau's sixth amendinent rights, even though Rideau could not demonstrate precisely how the pubhicity influenced his conviction. Although the Rideau Court did not so state, it is difficult to believe that the defendant's claim of presumptive prejudice would have been weaker had the print press alone covered his confession and then saturated the community with reports of it in local newspapers. ${ }^{175}$

When the Court decided Estes, however, it ignored the factual settimg of Rideau and instead rehed uncritically upon the earlier case to support the proposition that television and radio contaminate the crimmal justice system in a umque and incurable way. ${ }^{176}$ The Court thus interpreted Rideau, a case born of a peculiar combination of errors by the court and by law enforcement officials, as evidence of the general

170. See 62 A.B.A. Rep. 767 (1937). Canon 35 of the Canons of Judicial Ethics, the predecessor to Canon $3 \mathrm{~A}(7)$ of the Code of Judicial Conduct, was amended in 1952 to prohibit telecasting in addition to photography and broadcasting. 77 A.B.A. REP. 110-11, 257, 429-30, 607-11 (1952).

171. ABA Code of Judicial Conduct, Canon 3A(7).

172. By the time Estes was decided in 1965, all but two states-Texas and Colorado-had adopted what was then ABA Canon 35, thereby prohibiting television in the courtroom. 381 U.S. at 544.

173. 373 U.S. 723 (1963).

174. See Nebraska Press Ass'n v. Stuart, 427 U.S. 539 (1976).

175. See Sheppard v. Maxwell, 384 U.S. 333 (1966) (documenting intense print press coverage at a trial). In Sheppard, the Supreme Court found the coverage so excessive as to prejudice irremediably the defendant's trial. Although the case involved television and radio coverage, as well as newspaper coverage, the record in the Court contained only newspaper clippings.

176. 381 U.S. at 543-44. 
perniciousness of the broadcast industry. The Court presumed that Estes, like Rideau, was a victim of prejudice because the press used television cameras and microphones to cover his pretrial hearing and some portions of the trial itself. The Court did not require Estes to demonstrate any specific injury. It attached no weight to the fact that the televised pretrial proceeding in Estes was concerned with whether the court would permit cameras and broadcast equipment in the courtroom during the trial-not with matters bearing on guilt or innocence. ${ }^{177}$ Nor did the Court deem it relevant that under Texas law the jurors would be sequestered. ${ }^{178}$

Some of the force of Rideau and Estes has been blunted because the Supreme Court has revised its views on prejudicial publicity. After a decade of struggling with defendants' claims of presumptive prejudice from massive press attention by one or more of the media, ${ }^{179}$ the Court in Murphy v. Florida ${ }^{180}$ announced a stricter standard for measuring press prejudice. The Court held that a defendant's sixth amendment rights were not violated simply because some members of the jury knew of the defendant's exploits and prior record before the trial began. ${ }^{181}$ Nor was juror awareness of the trial's notoriety enough to trigger a finding of presumptive prejudice. ${ }^{182} \mathrm{Had}$ the Court failed to make this accominodation, a well-known or widely publicized defendant like Murphy would be virtually immune from conviction..$^{183}$

After Murphy a number of cases arose in which television publicity was an inportant factor in claims of prejudice. The government prosecuted several former White House aides to President Richard M. Nixon for their alleged roles in the 1972 Watergate conspiracy; their indictments stemmed from testimony before a Senate committee that

177. Id. at $535-36$.

178. $I d$. at 546 .

179. See Sheppard v. Maxwell, 384 U.S. 333 (1966); Estes v. Texas, 381 U.S. 532 (1965); Rideau v. Louisiana, 373 U.S. 723 (1963).

180. 421 U.S. 794 (1975).

181. One reason jurors had such information was that defense counsel, during the voir dire, pointed out numerous details about Murphy's past, including a recent murder conviction. Id. at $800 \mathrm{n.3}$. In addition to the information supplied during voir dire, and to evidence that jurors actually did harbor negative feelings toward a convicted felon like Murphy, the judge failed to instruct the jurors not to discuss the case among themselves, id. at 807 (Brennan, J., dissenting), and apparently took no other steps to insulate the jury from the publicity surrounding the case. Id.

182. Id. at 800 .

183. Despite the apparent complicity of the court and counsel in adding to the knowledge of the jurors about Murphy's past, the amount of pretrial publicity he generated would, in itself, probably have insured at least some "tainting" of the jury with extrajudicial prejudicial information. Murphy captured national attention for his role in the 1964 theft of the Star of India sapphire from the American Museum of Natural History in New York City. Id. at 795. 
millions viewed on nationwide television. Had television truly been "unique" in its prejudicial effects, a fair trial of these defendants would have been inpossible. Yet the Court of Appeals for the District of Columbia rejected the claims of the convicted Watergate conspirators that the pretrial publicity prejudiced their trial. ${ }^{184}$

Television may coinmunicate a different spectrun of information than the print media. ${ }^{185}$ The power to convey a unique message, however, does not render television uniquely prejudicial. No evidence supports the assumption that the mode by which one transmits information influences the degree of prejudice. No one has gathered scientific data that proves, or even suggests, that broadcast or photographic media are in this regard sui generis and distinguishable from the print media. ${ }^{186}$ The danger of press prejudice arises from the press's capacity to create an impression of guilt or innocence in advance of trial. The print inedia are no less adept at this than the broadcast media. ${ }^{187}$

During the trial itself, massive publicity, whatever the source, can create two difficulties for the defendant. First, publicity about the trial creates a risk that jurors will be influenced in their decision by exposure, from newspapers, magazines, radio, and television, to information

184. United States v. Haldeman, 559 F.2d 31, $59-71$ (D.C. Cir. 1976), cert. denied, 431 U.S. 933 (1977). People v. Manson, 6I Cal. App. 3d 102, 132 Cal. Rptr. 265 (1976), cert. denied, 430 U.S. 986 (1977), is another case in which overwhelming publicity, via television as well as the print press, was found not to have interfered with the fairness of the trial. The court relied on Murphy v. Florida, 421 U.S. 794 (1975) in reaching its conclusion, 6I Cal. App. 3d at 185, 132 Cal. Rptr. at 315.

185. See notes 100-05 supra and accompanying text.

186. The Supreme Court in Estes, 38I U.S. at 545, did not cite any authority for the proposition that television's presence in the courtroom "will have a direct bearing on [a juror's] vote as to guilt or innocence." The years since Estes have not supphed the empirical support that was missing at the time of the decision. While television is reportedly the medium upon which most people depend for news, and which they deem most credible, G. CoMstock, S. ChaffeE, N. Katzman, M. McCombs, \& D. Roberts, Television and Human BeHavior 9 (1978), it does not necessarily have unique power in comparison with other media im creating attitudes and beliefs. Preliminary research suggests that although television serves an "agenda-setting" function for the public, it does not influence how people think about things so much as what things they think about. Id. 315. Furthermore, all media are thought to be agenda-setters, and television may be less effective at it than are newspapers, at least with regard to certain types of political behavior. Id. 323-25. See K. Lang \& G. Lang, Politics and Television (1968):

No one has yet been able to "demonstrate" through a convincing experiment what the long-range effects of television have been. Nor are they likely to. To trace a change in a political climate or a realigninent within the electorate straight to the door of television is a task foredoomed to failure.

Id. 309-10. The Langs believe there may be "small incremental changes" in attitude, cumulative in effect, that can be attributed to the influence of television, but surely this must also be true of other modes of mass coinmunication.

187. See note 175 supra. 
about the case that has been ruled inadmissible. Second, should a retrial be necessary, publicity can make it more difficult to find another impartial jury.

Most cases attract so little press attention that neither of these problems ever occurs. The recognition of a right of technological access will not make publicity cases more common, because sucl cases result from their imtrinsic interest to the public, not from the mode of coverage. When the rare "publicity" case does occur, and media of all types cover it, there is no support for the assumption that actual footage of the trial will influence audiences in a way that merely hearing about the case, seeing sketches of it in the newspapers and on television, and reading detailed accounts of it would not. ${ }^{188}$ It is hard to imagine, for example, that live television coverage of Patricia Hearst's trial ${ }^{189}$ would have exacerbated the problems of empaneling a set of impartial jurors for a retrial, if one had been needed. ${ }^{190}$ The criminal justice system, in an age of rapid mass communication, must rely on change of venue, postponements, the basic ability of jurors to be fair-minded, and probing voir dire to cure the effects of publicity.

The risk that jurors will be exposed to prejudicial information during the trial is present whenever a trial attracts sufficient public interest to merit press coverage. The assumption that jurors actually heed the judge's admonitions against reading newspapers or listening to radio or television news during a trial is fundamental to our system of justice. ${ }^{191}$ When the risks of exposure are too great to rely merely on adnionitions, juries can also be sequestered.

188. Much of what is written about the influence of television on viewers seems to apply equally to other mass media. One author states: "While the focus [of this book] is on TV news, it will be clear that many of the points I make can also be applied to print journalism." $D$. ALtheide, CREATING Reality: How TV News Distorts Events 9 (1974). The Langs also make frequent observations which are equally valid for all media. See K. LANG \& G. LANG, stupra note 186 , at $150,290$.

189. See, e.g., N.Y. Times, Mar. 21, 1976, at 1, col. 8. Ms. Hearst was tried and convicted for her participation in crimes committed as a member of the Symbionese Liberation Army, the radical group that earlier had kidnapped her.

190. One sense in which technological access might make it more difficult to cmpanel a new jury would be that television is thought to reach a wider audience than newspapers, thereby decreasing the pool of "unaware" jurors. G. COMSTOCK ET AL., supra note 186, at 8 . Courts, however, have never regulated press coverage of events based on the size of the medium's circulation; to do so would be to penalize speech based on its effectiveness in reaching hearers, a policy surely inimical to first amendment values.

191. Exposure to press publicity is a risk not only with regard to jurors but also with respect to witnesses barred from the courtroom during testimony by others. The problems involved in keeping witnesses from viewing news about the trial are little different from those posed in keeping such publicity from jurors, and are unlikely to be aggravated by the presence of cameras and recording devices. But see Estes v. Texas, 381 U.S. at 547. 
Recognition of a right of technological access might increase the coverage of noteworthy trials, because broadcasters, able to present news about trials more effectively, might be willing to devote niore air time to it. And because many people rely primarily on television for their news, ${ }^{192}$ an increase in coverage might expose more people to such information. But the Supreme Court has never suggested that the government can control press coverage based on how effectively the media disseminate information. Consistent with the purpose of the first amendment, the press should not be regulated in proportion to the volume of news conveyed or the size of the audience reached. The increased coverage that technological access might bring is not a constitutionally sound basis for denying it. ${ }^{193}$

Permitting cameras in courtrooms might create one risk that does not exist when recording equipment is barred: jurors might succumb to the temptation to see their photographs in newspapers or on television. The State of Florida explored this possibility informally in a questionnaire distributed to jurors who served during that state's preliminary experiment with televised trials. Their responses suggested that most jurors experienced little or no curiosity. ${ }^{194}$ Apparently most of the states now experimenting with or permitting photography and broadcasting in their courts have not considered this possibility a significant threat; virtually all such states either place no restrictions whatever on photography of jurors or restrict such photograpliy only if the juror objects. ${ }^{195}$

192. See, e.g., G. Comstock et Al., supra note 186, at 8-9; M. Green, Television News: ANATOMY AND PROCESS 7 (1969). For a general exploration of the rising importance of television news, see H. LAND Assocs., Television AND THE Wired City (1968). Radio, hike television, is an important source of news and infornation. Radio today is thought to reach a wider audience than any other medium; it is estimated that the average American household now contams five radio sets. Waters, Sounds of Success, NEwSWEEK, Dec. 3, 1979, at 132.

193. Chief Justice Burger, writing for the plurality in Richmond Newspapers, Inc. v. Virginia, 100 S. Ct. 2814, 2825 (1980), implied that the first amendment protects the ability to reach a wide and varied audience when he wrote:

Instead of acquiring information about trials by firsthand observation or by word of mouth from those who attended, people now acquire it chiefiy through the primt and electronic media. In a sense, this validates the media claim of functioning as surrogates for the public. While media representatives enjoy the same right of access as the public, they often are provided special seating and priority of entry so that they may report what people in attendance have seen and heard. This "contribute[s] to public understanding of the rule of law and to comprehension of the functioning of the entire criminal justice system . . . ." Nebraska Press Assn. v. Stuart, 427 U.S. 539, 587 . . . (BRENNAN, J., concurring).

194. The Florida Supreme Court summarized the results of the survey: "The degree to which jurors and witnesses felt the urge to see or hear themselves on the media fell between not at all and slightly." In re Post-Newsweek Stations, Fla., lnc., 370 So. 2d 764, 769 (Fla. 1979).

195. Of the states whose temporary or perinanent rules on technological access place any restrictions on photography of jurors, most follow a model permitting such coverage unless jurors refuse to be photographed. See, e.g., Alaska: Canon 3A(7)(c)(iv), In re Canon 3A(7)(c), 5 Media L. Rep. 2494 (Alaska 1979); Oklahoma: Code of Judicial Conduc̀t, Revised Canon 3A(7) (Oct. 
One might also argue that jurors who see cameras in the courtroom may be influenced in their deliberations because the cameras make them aware that the case is unusually important or that the defendant is particularly notorious. ${ }^{196}$ Murphy $v$. Florida ${ }^{197}$ suggests that awareness of such matters is constitutionally imsignificant. Furthermore, the absence of cameras from the courtroom will not prevent the problein. Even without photographers and recording equipment anywhere in sight, jurors will be put on notice that a case is important once they see reporters with notebooks, artists with sketch pads and drawing boards, and large numbers of spectators filling up the available seats.

In sum, a right to record trials photographically and electronically will not create problems of intrusive publicity different from those caused by existing inedia coverage. In a publicity case, the increment of additional publicity that inay result from permittimg photograplis and tapes to be inade in court neither justifies a regulation of the press, nor changes the nature of the risks that publicity poses to the defendant's rights, nor alters the responsibility of the judge to protect the fairness of a trial. With or without the presence of modern journalistic technology, judges trying highly publicized cases must face the problein of shaping adequate protective orders, controlling the actions of court and law enforcement personnel, and deciding whether to use techniques such as sequestration of jurors or change of venue. Expandimg the possible metliods through which the press reports a trial to the public would place no additional or unique burdens on a court.

\section{Adverse Psychological Impact on Participants in Judicial Proceedings.}

The Supreme Court, soine states, and many meinbers of the bar have presuined that the presence of television cameras in the courtroom corrupts the process of justice simply because persons inside the courtroom have an "awareness that they are being televised." 198 This disability, it is said, attaches even though the cameras are unobtrusively

25, 1978); Washington: Code of Judicial Conduct 3A(7) (effective Sept. 20, 1976). Wisconsin's general prohibition on photographing jurors is unusual. See Wisconsin Supreme Court Order, In re: The Code of Judicial Ethics (June 21, 1979).

196. "[T]here are numerous situations in which televising court proceedings can cause an unfair trial . . . such as . . . improperly influencing jurors by emphasizing the notoriety of the trial and affecting their impartial judgenent . . . Callahan v. Lash, 381 F. Supp. 827, 833 (N.D. Ind. 1974) (granting a writ of habeas corpus because the trial was infected with numerous errors, including the adinission of television cameras to court). See also Estcs v. Texas, 381 U.S. at 545.

197. 421 U.S. 794 (1975).

198. Estes v. Texas, 381 U.S. at 545. See generally Doubles, supra note 146 (supporting a prohibition against technological access on privacy and psychological grounds). 
placed and are operated without distracting noises or disruptive physical movement. ${ }^{199}$ According to this theory, cameras make jurors and witnesses uncomfortable and self-conscious, ${ }^{200}$ tempt attorneys and judges into dramatic excesses or on-camera electioneering, ${ }^{201}$ and force criminal defendants to undergo an experience comparable to the third degree, disabling many of them so that they can no longer adequately participate in their own defenses. ${ }^{202}$ Such psychological disturbances, if real, would impair a criminal defendant's sixth ainendment rights, and might seriously impede justice im civil cases as well.

If these effects were truly as common and as severe as alleged, not even the recognition of first amendment protection for the means of news-gathering would win a place for cameras in the courtroom. In a balancing test, the need to prevent a significant impairment of the constitutional right to a fair trial would prevail over the right to technological access, because such impairment would conflict with the inost basic notions of due process. Evidence that these damaging disruptions actually occur, however, is at best quite speculative. Although Estes asserts that television, even when unobtrusive, is psychologically subversive, and that this is "common knowledge," the opinion cites no scientific data or studies for support. ${ }^{203}$

The small body of experience with teclinological access prior to the Estes decision actually supported the opposite conclusion. ${ }^{204}$ In

\footnotetext{
199. Estes v. Texas, 381 U.S. at 546 :

The State argues that [the effect on the jury] is de minimis since the physical disturbances have been eliminated. But we know that distractions are not caused solely by the physical presence of the camera and its telltale red lights. It is the awareness of the fact of telecasting that is felt by the juror throughout the trial. We are all self-conscious and uneasy when being televised.

200. Id. at 546,547 .

201. Id. at 546-49 (judges); $i d$. at 579 (Warren, C.J., concurring) (lawyers).

202. Id. at 549 .

203. Justice Clark, who wrote the majority opinion in Estes, referred several times to adverse psychological consequences of permitting television to film trials, 381 U.S. at 546, 547-48, 549, without citing any supporting scientific or empirical data. Chief Justice Warren, who also discussed the psychological inpact of television im his concurrence and who characterized that information as a matter of "common knowledge," cited newspaper articles, law review and bar association journal articles, and one lower court opinion, but no studies. Id. at 568-70. All the sources relied on by the Chief Justice were impressionistic writings.

204. Claims of prejudice from television, radio, or still photography were raised on numerous occasions before Estes, but were almost always defeated, even when the reviewing court expressed unhappiness as a matter of policy with the presence of such teclmology. The courts in each case were looking for evidence of actual effects on the trial, as opposed to applying the "presumed prejudice" rule enunciated in Estes, and were able to find none. See People v. Stroble, $36 \mathrm{Cal}$. 2d 615, 226 P.2d 330 (1951) (no reversible error despite an "inproper" permission to photograph and televise), affd sub nom. Stroble v. Cahfornia, 343 U.S. 181 (1952) (no claim of prejudice from coverage of the trial itself); Hudson v. State, 108 Ga. App. 192, 132 S.E.2d 508 (1963) (conviction reversed not because of the trial broadcast, which comports with the first amendment, but because
} 
Oklahoma, for instance, a defendant sought reversal of a conviction for burglary because of the psychological impact of television on his trial. ${ }^{205}$ Affirming the conviction, the appellate court noted the total absence of evidence of such an impact and therefore criticized the earher version of American Bar Association Canon 3A(7): "This contention presents itself as a baseless boogey constructed out of pure conjecture. We are of the opinion that the presumption upon which Canon 35 has been constructed is fabricated out of sheer imphication and not hammered out on the anvil of experience."206

Colorado, too, failed to find evidence that television or still photography caused any psychological disturbance. Justice Moore of the Colorado Supreme Court, who in 1956 refereed hearings on whether the state should reject Canon 35, reported that with one or two exceptions, he was not even conscious of the still, newsreel, and television caineras, or of the radio imicrophones, that were used to cover the

of the placement of a microphone too close to the defendant and his counsel); Bisignano v. Municipal Court, 237 lowa 895, 23 N.W.2d 523 (1946) (the court disapproved of the radio broadcast of contempt proceedings, but held that the defendant was not prejudiced); State v. Cox, $188 \mathrm{Kan}$. 500,363 P.2d 528 (1961) (a radio broadcast of pretrial proceedings, while disapproved, was not reversible error); State v. Langley, 214 Or. 445, 323 P.2d 301 (1958) (the use by the press of movie and still cameras in court was not reversible error). But see People v. Ulrich, 376 Ill. 461, 34 N.E.2d 393 (1941) (revcrsing a conviction for inadequate proof and reinforcing that decision by disapproving of the use of still cameras in the court). Interestingly, two of the most notorious trials at which cameras and broadcast equipment were used were that of Bruno Hauptmann, kidnapper of the son of Charles A. Lindbergh, and that of a Colorado man who, in order to murder his mother, blew up a commercial airliner. In neither appeal were the cauneras and inicrophones identified as giving rise to special problems of prejudice. Grabam v. People, 134 Colo. 290, 302 P.2d 737 (1956) (no claim of prejudicial publicity raised); State v. Hauptmann, I15 N.J.L. 412, 180 A. 809 (im affirming the conviction, the court does not mention the use of radio microphones or newsreeI cameras in the courtroom), cert. denied, 296 U.S. 649 (1935). The strongest language opposing technological access is found not in crimmal appeals, but in contempt actions against the press for violating court orders against the taking of photographs. See Brumfield v. State, 108 So. 2d 33 (Fla. 1958); Ex parte Sturm, 152 Md. 114, 136 A. 312 (1927); State v. Clifford, 162 Ohio St. 370,123 N.E.2d 8 (1954). Interestingly, in Brumfield the Florida court stressed that the taking of photographs did not "cause inordinate disturbance or indignities," 108 So. 2d at 34-35. In Ex parte Sturm, photographs were taken in court so unobtrusively-but secretly and in violation of a court order - that the judge was not aware of thein until two were run in a local newspaper, 152 Md. at 117, 136 A. at 313 (1927). In another case, In re Greenfield, 163 N.E.2d 910 (Ohio Ct. App. 1959), the contempt conviction of a photographer for taking pictures of the trial through a window in the courtroom door was reversed because the court found no interference witb the administration of justice as a result of Greenfield's activities: "If there was any obstruction of justice by anyone, it was the court bailiff who 'called to the court's attention' the taking of pictures through a window of the closed door .... The record does not show that the court was disturbed by this act until notified by the bailif:" 163 N.E.2d at 912 .

205. Lyles v. State, 330 P.2d 734 (Okla. Crim. App. 1958).

206. Id. at 742 . The court referred, in support of the assessinent, to its own experience with televised proceedings. 
proceedings. ${ }^{207}$ While long exposure to the public may have conditioned Justice Moore to these devices, later experience in Colorado courtrooins suggested that others less accustomed to public exposure were similarly immune. The first trial televised in Colorado after the state court rejected Canon 35 was a celebrated murder case in which the state accused the defendant of concealing a bomb aboard an airliner.208 Subsequent interviews with participants and with the defendant's widow 209 revealed that once the trial began, no one--froin judge to jury-was conscious of the cameras that recorded the events in the courtroom. ${ }^{210}$

Since Estes, no one has gathered authoritative evidence to support the Court's assumption that disruptive emotional effects result from televising trials. ${ }^{211}$ Most sociological and psychological research to date has addressed the effects of the inass media on the audience rather than on the subjects of coverage theinselves. ${ }^{212}$ One research teain reported

207. In re Hearings Concerning Canon 35 of the Canons of Judicial Ethics, 132 Colo. 591, 595, 296 P.2d 465, 468 (1956).

208. Graham v. People, 134 Colo. 290,302 P.2d 737 (1956).

209. Graham, the defendant, had been executed before the interview with his wife took place. Broadcasting in the Courtroom, BROADCASTING, May 13, 1957, at 136.

210. Id. The foreman of the jury stated in the interview that he forgot about the television cameras once the trial began. He observed of others in the case: "I imagine that [the witnesses] would be just a little nervous anyhow, but $I$ do not believe the attorneys, the defendant, or anyone else was conscious that the cameras were there." Id. 140.

211. The strongest indication that a factual basis for Estes has been found wanting is the current trend among the states to reject the $\mathrm{ABA}$ position and to inodify Canon $3 \mathrm{~A}(7)$ to permit electronic and film coverage by the media. See note 21 supra. In addition, the few cases since 1965 in which technological coverage was alleged to have prejudiced the defendant have generally been decided against the defendant. The first of the highly publicized criminal trials to be televised in Florida after it began its modern experiment was that of Ronny A. Zamora for murder. He was convicted, and on appeal did not even raise any claims based on the presence of cameras in the court. Zamora v. State, 361 So. 2d 776 (Fla. Dist. Ct. App. 1978), cert. denied, 372 So. 2d 472 (Fla. 1979). See Bradley v. State, 470 F.2d 785 (5th Cir. 1972) (although the court expressed disapproval, it refused to overturn a denial of a writ of habeas corpus and the finding of the district court that still and television cameras did not prejudice the Colorado defendant in a state court criminal trial); Bell v. Patterson, 279 F. Supp. 760 (D. Colo.) (the televising of a verdict has no impact on due process), affd, 402 F.2d 394 (10th Cir. 1968), cert. denied, 403 U.S. 955 (1971); Gonzales v. People, 165 Colo. 322, 438 P.2d 686 (1968) (the court found no impact froin a television camera in the courtroom and no unusual publicity surrounded the trial); $c f$. United States v. CBS, Inc., 497 F.2d 102 (5th Cir. 1974) (sketching in court did not affect the participants); In re NBC, 64 N.J. 476, 317 A.2d 695 (1974) (the court accepted the claim of the petitioners that the sketching of trials would not distract or influence witnesses or jurors); State v. Wampler, 30 Or. App. 931, 569 P.2d 46 (1977) (the presence of television and lights in the hall outside the courtroom did not distract the jury or damage the defendant's rights), cert. denied, 436 U.S. 960 (1978). But see Callahan v. Lash, 381 F. Supp. 827 (N.D. Ind. 1974) (a writ of habeas corpus issued because there were numerous sources of prejudice, including the presence of television and flash cameras).

212. For an overview of research in the area, see generally G. CoMsTOCK ET AL., supro note 186. 
that television cameras could be used to create in individuals a state of "objective self-awareness": a greater consciousness of self than of environment.213 Subsequent studies suggest, however, that this state of acute self-consciousness wears off quickly, either because subjects find it too uncomfortable to sustain or because they adjust to it rapidly.214 Furthermore, the research does not suggest that only cameras instill self-consciousness; observation by a live audience of strangers may produce similar effects. ${ }^{215}$

Florida's informal study of how participants reacted to televised trials showed that witnesses and jurors knew of the camera's presence, but responded to that awareness with only slight self-consciousness. ${ }^{216}$ This self-consciousness, moreover, did not decrease the jurors' concentration on the trial; several jurors commented that their awareness of the cameras actually increased their sense of responsibility. ${ }^{217}$

The most thorough attempt to assess the psychological impact of cameras on trial participants comes from California, which elaborately evaluated the extent to which the courts could use videotape to improve the criminal justice system. ${ }^{218}$ The state studied the reactions to videotaping of witnesses at depositions and at pretrial hearings. ${ }^{219}$ The study failed to demonstrate that the camera caused any psychological stress. One-third of the witnesses in the study reported nervousness or discomfort, but they attributed these feelings largely to the behavior of the examining attorney or the presence of the defendant in the courtroom. ${ }^{220}$ There was no evidence that witnesses were reluctant to

213. See generally $\mathrm{S}$. Duval \& R. Wicklund, A Theory of Objective Self-Awareness (1972); Davis \& Brock, Use of First Person Pronouns as a Function of Objective Self-Awareness and Performance Feedback, 11 J. EXPERIMENTAL SOC. PSYCH. 381 (1975).

214. S. Duval \& R. WICKLUND, supra note 213 , at $23-24$. The article by Davis \& Brock, supra note 213 , at $386-87$, suggests that positive feedback may prolong the state of self-awareness in a subject by making the experience pleasant. This study does not address the suggestion, however, that adjustment ordinarily occurs fairly quickly.

215. Mirrors and tape recordings of the subject's own voice have been used to induce the state by experimenters. See Davis \& Brock, supra note 213, at 381-82.

216. The Florida Supreme Court reports that awareness of the cameras ranged from slight to moderate; respondents reported they felt "slightly self-conscious" in the camera's presence but were unaffected in their ability to participate effectively in the proceedings. In re Post-Newsweek Stations, Fla., Inc., 370 So. 2d 764, 768 (Fla. 1979).

217. "Both jurors and witnesses perceived that the presence of electronic media made them feel just slightly more responsible for their actions." $I d$. The survey also found that some respondents believed themselves "slightly . . . more attentive" in the presence of the cameras. Id.

218. ERNEST H. SHORT \& AsSOCS., INC., supra note 114.

219. Id. $27-41$.

220. Id. 28-29:

During the second phase of this research, witnesses were asked, "When you gave your testimony, was there anything im particular that made you nervous or bothered you in any way?" While over 35 percent of the witnesses sampled answered yes to this question, when asked to explain, none of the witnessess attributed their nervousness to the video- 
participate in videotaped proceedings, or that they had a negative attitude toward them.221

The researchers ultimately concluded:

It is entirely possible that videotape recording produces stresses that are either so small as to be undetectable or so short lived as to be immeasurable. . . [A]lthough witnesses may be aware of the presence of the videotape apparatus, this awareness is of little consequence when compared with the pressures and demands made upon witnesses as part of the normal testimony process. ${ }^{222}$

Stress at the levels noted by the California research-nonexistent or too trivial to measure-hardly constitutes a sixth amendment violation or provides a sufficient state interest to limit a first amendment right. The conclusions of the California study corroborate the experience of courts like Florida's, in which the press, rather than the court, operated videotape recorders without distracting the participants from the trial. 223

Although the author found no evidence directly on the poimt, there is little reason to predict that televised trials would disproportionately distress defendants im a criminal case. Little is known about the psychological effects of cameras on unwillingly televised defendants because many states require the defendant's consent prior to televising his trial.224 By extrapolation from what is known about jurors and

tape recording. The two most frequently mentioned causes of nervousness were the behavior of the examining attorneys ( 46 percent) and the presence of the suspect ( 19 percent).

221. Id. 29 .

222. Id. 30 .

223. See note 216 supra. Further reinforcement may be found in the fact that television reporters have covered many solemn and important events outside of courtrooms without causing disruptions. For a discussion of events other than trials that have been televised without incident in recent years, see CONG. RESEARCH SERv. FOR JOINT COMM. ON CONGRESSIONAL OPERATIONS, 93 Cong., 2d Sess., Congress and Mass Communications: An Institutional Perspective 44-47 (Comm. Print 1974); N. Minnow, J. Martin, \& L. Mitchell, Presidential Television 17-68 (1973).

224. The requirement of prior consent is responsive to the comment in Estes that Estes opposed the presence of television, still cameras, and radio at his trial and that his consent might have erased the due process violation, 381 U.S. at 535 . As a result, many states require the defendant's consent to be obtained before they will permit technological access to a trial. See, e.g., Alabama: Canons of Judicial Ethics, Canon $3 A(7)(A), 3 A(7)(B)$; Georgia: Code of Judicial Conduct, Canon 3A(8); Oklahoma: Code of Judicial Conduct, Revised Canon 3A(7). Colorado, which continued to permit televised trials after Estes, revised its rule to require prior consent by the accused. Cal. Assembly Interim Comm. on Judiciary, Report of the Subcomm. on Free Press-Fair Trial, 23 Assembly Interim Comm. Rep. 13 (1965-66) (remarks of Justice Moore, Colorado Supreme Court); Colorado, Canons of Judicial Ethics, Canon 3A(8)-(10). One of the few states to dispense with the requirement that the defendant agree to pictorial or broadcast coverage is Florida. See Code of Judicial Conduct, Canon 3A(7) (effective May 1, 1979). Other states that have dispensed with the prior consent of the defendant include Montana (Canons of Judicial Ethics, Revised Canon 35 (effective April 1, 1978) (two-year experiment)); New Hampshire (Code of Judicial Conduct, Canon 3A(7), and Superior Court Rule 78(a) (effective Jan. 1, 
witnesses, however, it seems likely that the addition of cameras and recorders would not significantly imcrease the defendant's psychological burden. A person accused of a crime, confronting the possible loss of freedom, facing hostile or damaging witnesses, and enduring the scrutimy or censure of family, friends, the press, and strangers, is under considerable stress; the accused is unlikely to find that unobtrusive cameras or microphones noticeably increase the stress.

Experience has also failed to show that the presence of cameras and microphones induces attorneys and judges to abandon decorum and play to their unseen audience. States that have televised trials report no such problein.225 Soine commentators, reviewing the effect of television on a reasonably comparable group-state legislators-determimed that the presence of the cameras actually mcreased the dignity of their behavior. ${ }^{226}$ Reports suggest that legislators prepare more carefully for debates and hearings when they know they will be publicly scrutinized; in one state, legislators stopped eating lunch and reading newspapers in the chamber. ${ }^{227}$

In any case, courts should not restrict the press merely because some judges and attorneys misbehave before cameras. As Justice Moore tartly observed $\mathrm{m}$ rejecting the proscriptions of Canon 35 in Colorado, "a constitutional right of all citizens cannot be denied because a very few persons may conceivably make fools of themselves before a larger audience than that which might otherwise be subjected to their offensive conduct."228 The legal profession must develop appropriate standards for controlling courtroom behavior. The press and the public should not be penalized for the profession's failure to do so.

\section{Invasion of Trial Participants' Rights of Privacy.}

Judges and attorneys, deeply conscious of the personal distress and embarrassment experienced by many who come unwillingly before the courts, are understandably concerned with protecting these individuals' interest in privacy. Courts have sought to afford such protection by preventing technological access, thereby restricting publicity. Although

1978)), and New Jersey (New Jersey Supreme Court Order (Mar. 15, 1979) (establishing trial period for the experimental use of cameras and broadcast coverage of trials)).

225. See In re Post-Newsweek Stations, Fla., Inc., 370 So. 2d 764, 775-76 (Fla. 1979); Cal. Assembly Interim Comm., supra note 224, at 13 (remarks of Justice Moore, Colorado Supreme Court).

226. See generally Twentieth CentuRY Fund TASK ForCE, supra note 27, at 73-87; In re Post-Newsweek Stations, Fla., Inc., 370 So. 2d 764, 780 (Fla. 1979). For a contrary view, see Smile, You're On . ., 65 A.B.A.J. 1168 (1979) (reporting that House Speaker Thomas O'Neill (D. Mass.) believes television has slowed proceedings by encouraging members of Congress to talk more).

227. See In re Post-Newsweek Stations, Fla., Inc., 370 So. $2 \mathrm{~d} 764,780$ (Fla. 1979).

228. In re Hearings Concerning Canon 35 of the Canons of Judicial Ethics, 132 Colo. 591, 599, 296 P.2d 465, 470 (1956). 
the press and public traditionally have been allowed to attend all but the rare trial, ${ }^{229}$ courts have used privacy to justify excluding the reporters' recording paraphernalia. ${ }^{230}$ Although tape recorders and microphones have some capacity to create privacy problems, the primary concern has focused on still, movie, and video caineras. Pictures, critics reason, may make a juror or a defendant recognizable to strangers on the street, in contrast to mere verbal or written reports which do not pose the saine risk. As a result, participants in trials may find themselves subjected to harassment or embarrassment. ${ }^{231}$

Certainly, publication or broadcast of pictures taken in court may increase public recognition; but protection of privacy is neither practically nor legally a justification for barring caineras from the courtroom. On the practical side, the ban on caineras, by necessity linited to the courtroom and its immediate surroundings, does not prevent aggressive reporters from getting the pictures they want. ${ }^{232}$ Defendants, witnesses, and even jurors are frequently photographed on the public streets outside the courthouse as they enter and leave, negating the usefulness of proscriptions agamst technological access to prevent the most serious cases of mtimidation. ${ }^{233}$

229. Even in Gannett Co. v. DePasquale, 435 U.S. 368 (1979), permitting the exclusion of the public and press from pretrial hearings in criminal cases, the United States Supreme Court emphasized strongly the long and firm common law tradition of open courts that exists in the United States and England. Some types of trials may be closed as a matter of public policy, but these are exceptional. Typical examples include juvenile proceedings and adoptions, English v. McCrary, 348 So. 2d 293, 301 \& n.10 (Fla. 1977); see Weinstein \& Zimmerman, supra note 109, at 158-60 \& nn. 11-17. But see Lexington Herald Leader v. Tackett, 49 U.S.L.W. 2041 (Ky. June 24, 1980) (improper for trial court to close the courtroom during testimony of ten children who were sodomy victims); State ex rel, Oregonian Publishing Co. v. Deiz, 613 P.2d 23 (Or. 1980) (state law that excludes the press and public from juvenile courts unless the child or the parents request a public proceeding violates the state constitution).

230. See Tribune Review Publishing Co. v. Thomas, 153 F. Supp. 486, 494-95 (W.D. Pa. 1957) (the court denied the newspaper an injunction against the enforcement of a state court rule banning photographs in court and environs, partially on the grounds that the state must protect the privacy of defendants); Ex parte Sturm, 152 Md. 114, 118, 136 A. 312, 314 (1927) (the court affirmed the contempt convictions of photographers who took pictures of a defendant in a courthouse and courtroom, in part to protect a defendant's privacy interest); In re Mack, $386 \mathrm{~Pa}$. 251, 259,126 A.2d 679, 683 (1956) (the court recognized the duty of courts to protect the privacy of criminal defendants against unwanted photographs), cert. denied, 352 U.S. 1002 (1957).

231. Estes v. Texas, 381 U.S. at 546. The problem of protecting jurors from harassment is not unique, of course, to cases that are televised or photographed. See, e.g., United States v. Barnes, 604 F.2d 121 (2d Cir. 1979) (approving the trial court's decision to protect the anonymity of jurors in a narcotics case by refusing to make public their names and addresses), cert. denied, $100 \mathrm{~S}$. $\mathrm{Ct}$. 1833 (1980).

232. Moreover, any person motivated to harm or harass a trial participant can go to court personally to identify his target. See, e.g., United States v. Barnes, 604 F.2d 121 (2d Cir. 1979), cert. denied, 100 S. Ct. 1833 (1980).

233. Courts generally accept the right of the press to report on and photograph events in public places, see, e.g., Galella v. Onassis, 487 F.2d 986, 998 (2d Cir. 1973) (a photographer's ability to 
Moreover, the legal system does not normally recognize or protect an individual privacy interest in avoiding public exposure of the fact or nature of one's participation in a trial. That is not to say that privacy is a legally insignificant interest. There are situations, however, in which privacy interests must yield to countervailing rights. The Supreme Court has suggested that citizens must pay the price of a considerable vulnerability to public scrutimy in exchange for the right of free speech. ${ }^{234}$ In Cox Broadcasting Corp. v. Cohn, ${ }^{235}$ for example, the Court declared it unconstitutional to subject a newspaper to damages for publishing the name of a rape victim when that name was obtained from public court records. Cox Broadcasting supports the view that the first amendment does not permit privacy interests to mfringe on the press's right truthfully to report the events that transpire in a courtroom. The common law, too, has evolved a principle of immunity from actions for invasions of privacy that protects the right of truthful coverage of public legal proceedings. ${ }^{236}$ Courts have applied this common law principle to both civil and criminal trials. ${ }^{237}$ Furthermore, courts have not distinguished between parties and other trial participants. ${ }^{238}$

cover Jacqueline Kennedy Onassis in public should not be unreasonably restricted); Channel 10 , Inc. v. Gunnarson, 337 F. Supp. 634 (D. Minn. 1972) (the unedia has a right to gather information, including photographically, in public places); Gill v. Hearst Publishing Co., 40 Cal. 2d 224, 230 , 253 P.2d 441, 445 (1953) (no recovery for the pubiication of a photograph taken in the Los Angeles Farmers Market). See generally 3 Restatement (SECOND) of ToRTs $\$ 652 D$, comment b at 385 (1977); W. Prosser, LAW OF TORTS $\$ 117$, at 808-09 (4th ed. 1971).

234. Time, Inc. v. Hill, 385 U.S. 374, 388 (1967): "Exposure of the self to others in varying degrees is a concomitant of life in a civilized community. The risk of this exposure is an essential incident of life in a society which places a primary value on freedom of speech and of prcss."

235. 420 U.S. 469 (1975). See also Smith v. Daily Mail Publishing Co., 439 U.S. 963 (1979) (the state's desire to protect privacy is an insufficient justification for preventing the press from publishing the name of a juvenile in criminal court proceedings).

236. 420 U.S. at 493-95. Accord, Elmhurst v. Pearson, 153 F.2d 467 (D.C. Cir. 1946) (a defendant in a nationally publicized criminal trial cannot sue for invasion of privacy because the reporter was privileged to report about him); Edmiston v. Time, Inc., 257 F. Supp. 22 (S.D.N.Y. 1966) (the press is privileged to report about the sexual conduct of a complaining witness in a rape case); Berg v. Minneapolis Star \& Tribune Co., 79 F. Supp. 957 (D. Minn. 1948) (a party to a custody battle has no right to privacy where his photograph was published to illustrate a newspaper story about the proceedings); $c f$. Randolph v. Wheeler, 223 F. Supp. 260 (S.D. Cal. 1963) (the publication by the House Un-American Activities Committee of names of subpoenaed witnesses did not give the plaintiff a cause of action for invasion of privacy); Irwin v. Ashurst, 158 Or. 61,74 P.2d 1127 (1938) (a radio station was not liable for defamation for broadcasting libellous statements by a defense counsel about a witness in a murder trial). See also 3 Restatement (SECOND) OF TORTS $\S 611$, comment d at 299 (1977); W. PROSSER, LAW OF TORTS $\S 118$, at $830-33$ (4th ed. 1971).

237. Compare Elmhurst v. Pearson, 153 F.2d 467 (D.C. Cir. 1946) (the invasion of privacy claimed by a defendant in a notorious criminal trial) with Berg v. Minneapolis Star \& Tribune Co., 79 F. Supp. 957 (D. Minn. 1948) (the invasion of privacy claimed by a party to a divorce and custody proceeding).

238. Compare Edmiston v. Time, Inc., 257 F. Supp. 22 (S.D.N.Y. 1966) (a claim of invasion of 
Thus, individuals appearing in public court proceedings ordinarily have no right of privacy that screens them from public knowledge. Occasionally an entire proceeding or part of one may be held in camera to protect some class of individuals-juveniles accused of crimes, for example-that the court or the legislature deems especially vulnerable to public exposure. ${ }^{239}$ These exceptions, however, are rare and are normally made after the legislature determines that secrecy better serves not only that individual's interests, but the public interest as well.

Bans on recordimg equipment at trials open to the public cannot be supported on the same grounds that justify a total closing of judicial proceedings. By opening the courtroom to the public, the courts have made the judgment that the interest of defendants in publicity and the right of citizens to observe and discuss the operations of the judicial system outweigh any countervailing interests of participants in secrecy. ${ }^{240}$ The decision to bar cameras, microphones, and tape recorders can thus best be described as a coinpromise that does not prevent the public exposure of litigants and others, but inerely limits the nature of that publicity.

Framed in this way, the difficulty becomes immediately apparent. Bans on cameras and recorders discriminate against the photographic and electronic media's ability to gather news effectively; the bans aim at the partial protection of trial participants' privacy interests. The privacy imterest, however, has been regularly sacrificed to free speech and to the public interest in open trials. Absolute prohibitions against technological access to protect privacy are therefore probably unconstitutional. 241

\section{E. Content-Based Objections to Cameras in the Courts.}

Despite exceptions like obscenity, ${ }^{242}$ libel, ${ }^{243}$ and fighting words, ${ }^{244}$

privacy by a witness in a criminal trial) with Berg v. Minneapolis Star \& Tribune Co.. 79 F. Supp. 957 (D. Minn. 1948) (a claim of invasion of privacy by a party to a civil proceeding).

239. See note 229 supra. See also N.Y. JuD. LAw $\$ 4$ (McKinney 1968).

240. See Cox Broadcasting Corp. v. Cohn, 420 U.S. 469 (1975).

241. One recent federal case dealt with a prisoner's privacy rights. A tape recording of the defendant banging on his cell door and shouting was broadcast, and the defendant complained of an invasion of privacy. The Court of Appeals for the Eighth Circuit ruled that when no claim of invasion of privacy would otherwise exist, the taping of defendant's remark did not give rise to a cause of action. Holman v. Central Ark. Broadcasting Co., 610 F.2d 542 (8th Cir. 1979).

242. See, e.g., Miller v. California, 413 U.S. 15 (1973).

243. See, e.g., Gertz v. Robert Welch, Inc., 418 U.S. 323 (1974).

244. See Chaplinsky v. New Hampshire, 315 U.S. 568 (1942) (later subsumed by the clear and present danger test, see Cohen v. California, 403 U.S. 15 (1971)). 
a basic tenent of first amendment theory is that speech cannot be regulated according to its content or because it is deeined to be socially undesirable. ${ }^{245}$ Judges cannot shape speech to conform with their notions of its merit; ${ }^{246}$ good taste is not the sine qua non of protected speech. ${ }^{247}$ Furthermore, the first amendment gives no preference to speech that informs over speech that "merely" entertains. 248 The Constitution leaves choices about what to say to coinmunicators. Although eroded by special access and fairness requirements for broadcasting, 249 the principle that content-based restraints on speech are invalid remains at the core of first amendment jurisprudence.

It is difficult to find this basic tenet of first amendment law in the language with which commentators and judges have justified bans on television in the courts, because so unuch of what they say is couched in terms of disapproval of television, its content, and its style of presenting information. The American Bar Association's earlier version of Canon 3A(7), Canon 35 of the Canons of Judicial Ethics, explicitly stated that one reason to keep radio and television out of the courts is to avoid the risk that those media might create "misconceptions" about the courts in the minds of the public. ${ }^{250}$ Chief Justice Warren, concurring in Estes, explained the Court's ruling partly on the grounds that, were trials routinely televised, the public might "equate the trial process with the forms of entertainment regularly seen on television and with the com-

245. "[A]bove all else, the First Amendment means that the government has no power to restrict expression because of its message, its ideas, its subject matter, or its content." Police Dep't v. Mosley, 408 U.S. 92, 95 (1972). But see Beauharnais v. Illinois, 343 U.S. 250, 261 (1952) (criminal libel statute upheld).

246. A sampling of United States Supreme Court cases from the past two decades, including New York Times Co. v. Sullivan, 376 U.S. 254 (1964), as well as more recent eases like Smitll v. Daily Mail Publishing Co., 439 U.S. 963 (1979), suggests that the Court will be unwilling to punish or proscribe speech even when claimants make assertions of harm that have long been recognized as deserving of legal remedy.

247. For example, the Court in Erznoznik v. City of Jacksonville, 422 U.S. 205 (1975), overturned a ban on all nudity on drive-in theater screens despite the fact that the images could be seen from surrounding public streets.

248. Winters v. New York, 333 U.S. 507 (1948).

249. See notes 7-16 supra and accompanying text.

250. 62 A.B.A. REP. 14 (1937); amended to add the phrase "or telecasting," 77 A.B.A. REP. 429, 607 (1952). The text of Canon 35 as amended, stated that

[p]roceedings in court should be conducted with fitting dignity and decorum. The taking of photographs in the court room, during sessions of the court or recesses between sessions, and the broadcasting or telecasting of court proceedings are calculated to detract from the essential dignity of the proceedings, degrade the court and create misconceptions with respect thereto in the mind of the public and should not be permitted.

Id. (emphasis in original). 
mercial objectives of the television industry."251 The Chief Justice expressed concern that scenes from trials might be aired side-by-side with advertisements for "soft drinks, soup, eyedrops and seatcovers."252 In so stating he chose to ignore that newspapers also carry advertising, and that they are likely to report Supreme Court opinions side-by-side with advertisements for lingerie or supermarket specials.

The Court is not alone in justifying the exclusion of cameras because of a distaste for the content and "bad tendencies" of television coverage. The American Bar Association's Special Committee on Televising and Broadcasting Legislative and Judicial Proceedings expressed fears that television reports of sensational trials might have an "injurious effect on public morals."253 Others have worried that television news directors would distort coverage by showing only limited parts of a proceeding. ${ }^{254}$ When press advocates responded that all forms of reporting edit, and therefore distort, the ABA's reaction was simple: that print journahists distort coverage is no reason to make tlimgs worse by giving television and radio journalists the opportumity to do so as well.255 Some of the arguments suggest that teclinological access should be controlled because television communicates more effectively, or to a larger audience, than do newspapers and books. ${ }^{256}$

251. 381 U.S. 532,571 (1965).

252. Id.

253. 77 A.B.A. REP. 610 (1952):

The experience thus far with radio broadcasting and motion pictures of trials has shown that ouly the most sordid crimes are likely to be televised. In addition, the undue publicity from the telecasting of criminals may pander to the desire of abnormal crimmal minds for mock heroics and resulting fame. To sensationalize such trials by television can have but an injurious effect on public morals.

254. 77 A.B.A. Rep. 609 (1952); Free Press and Fair Trial Hearings Before Subcomm. on Human Rights and Subcomm. on Improvements in Judicial Machinery of the Senate Comm. on the Judiciary, 89th Cong., Ist Sess. 400 (1965) (statement of Justice Abraham N. Geller); U.S. NEws \& WORLD ReP., Apr. 17, 1978, at 51 (interview with attorney John Sutro of California); $c f$. Estes v. Texas, 381 U.S. at $547-48,574$ (prospective jurors, if called in a retrial, would have seen only the state's view of the case against Estes).

255. 77 A.B.A. Rep. 609 (1952) (Report of Special Committee on Televising and Broadcasting Legislative and Judicial Proceedings): "Your committee is well aware that newspaper reports may also by their necessary brevity give a distorted impression of the facts, but this regrettable circumstances affords no justification for further distortion incident to the use of television and broadcasting."

256. The various opinions in Estes are replete with references to the power of television over its audience. For imstance, Chief Justice Warren, concurring, stated that

[b]roadcasting in the courtroom would give the television industry an awesome power to condition the public mind either for or against an accused. . . Moreover, if the case should end in a mistrial, the showing of selected portions of the trial, or even of the whole trial, would make it almost impossible to select an impartial jury for a second trial. . . . To permit the powerful medium to use the trial process itself to influence the opinions of vast numbers of people... would be entirely foreign to our system of justice.

381 U.S. at 574. See also the discussion of prejudicial publicity, notes 164-96 supra and accompanying text. For a contemporary expression of similar concern over the effects of television on the 
To state the arguments is to expose their inconsistency with first amendment jurisprudence: they seek to discriminate against television because of its content. The arguments are important not on their merits but because they suggest the unarticulated basis for the passionate resistance to technological access. "The Press," for some, is a subject fraught with emotion. Mass media generally, and television particularly, have often been viewed as a social "problem" of alarming dimensions, as institutions which damage rather than promote the common welfare. ${ }^{257}$ This distrust appears to be reflected $\mathrm{m}$ the process by which the $A B A$ drafted, and the states adopted, the original version of Canon $3 A(7)$.

The history of the legal reaction to the communications revolution illuminates the deeply rooted nature of this distrust. The decades of the 1920s and 1930s saw radio link together an enormous nation. ${ }^{258}$ At the same time, the motion picture, telegraph, and telephone-all still rela-

impressions of the audience and the fairness of the proceedings, see Tribe, supra note 147. The Supreme Court has firmly rejected the suggestion that, absent a clear and present danger to safety, national security, or other compelling interests, speech can be regulated because of its effectiveness, or its undesirable influence on an audience. See, e.g., Brandenburg v. Ohio, 395 U.S. 444 (1969) (per curiam) (reversing the conviction of a Ku Klux Klan leader under a criminal syndicalism statute).

257. During the 1960 s all mass media were heavily criticized, but none more so than television. Television was accused of desensitizing its viewers to a point at which they would watch a murder without intervening to help the victim. See, e.g., H. SKouRNia, Television AND THE News: A Critical Appraisal 181 (1968). It was also accused of causing viewers to become violent themselves, although scientiflc evidence was and remains questionable. M. GREEN, supra note 192, at 308. Television was alleged to influence the events it portrayed, helping to fan civil unrest into race riots, $i d$, and then, by its intensive coverage, prolonging the disturbances and raising the level of emotional tension. Dunne, $T V$ 's Riot Squad, New Republic, Sept. 11, 1965, at 27. See also H. SkourNIA, supra, at 23. Marshall McLuhan's controversial writings on the mass media emphasized their potential for manipulating the states of mind of whole masses of people:

We are certainly coming within conceivable range of a world automatically controlled to the point where we could say, "Six hours less radio in Indonesia next week or there will be a great falling off of literary attention." Or, "We can program twenty more hours of TV in South Africa next week to cool down the tribal temperature raised by radio last week.["] Whole cultures could now be programmed to keep their emotional climate stable in the same way we have begun to know something about maintaining equilibrium in the commercial economics of the world.

M. MCLuhan, Understanding Media: The Extensions of Man 28 (1964). The concern over television is, however, not unlike that generated by other, earlier media; G. CoMSTOCK ET AL. supra note 186, at 485: "Social and behavioral science did not invent anxiety over the impact of the mass media. It has existed since the first newspapers and popular periodicals. Comic books, pulp fiction, and movies have all been targets of attack."

258. Guglielmo Marconi transmitted the first radio signals in 1895. Commercial use of the radio began in a limited way in 1919 . By 1925 , the use of the air waves had grown so rapidly that interference among stations became a serious problem. Federal legislation to control the chaos on the airwaves was passed in 1927. D. GinsBurg, Regulation OF BroADCASTING: LAW AND Policy Towards Radio, Television and Cable Communications 9-10 (1979). Radio became a major source of news and entertainment during the 1930 s, only to lose its status to the newer medium of television following World War 11. Id. 243. See also NBC v. United States, 319 U.S. 190, 193, 197-98 (1943). 
tively recent innovations-contributed to the revolution in inan's ability to communicate quickly over great distances. ${ }^{259}$ When the legal community perceived a need to control the explosion in mass communications, it focused attention on the relatively unfamiliar media of radio and still and newsreel plootography. ${ }^{260}$

Distrust of television increased during the 1960s, a decade of accelerated development in modern communications. Television ceased to be a toy and suddenly became a major disseminator of news and entertainment. ${ }^{261}$ Some feared that television miglit displace entirely movies, radio, and books. ${ }^{262}$ The overwhelming cultural impact of television, which brought distant events directly and realistically into American living rooms, sometimes led to confusion between the medium and its message. Many suspected television of collaboratimg in or even causing the turbulent events it reported. ${ }^{263}$

It is probably not coincidental to the result in Estes that the Supreme Court had already taken a position on the relationship between broadcasting and the federal judiciary. Rule 53 of the Federal Rules of Criminal Procedure prolibits plotography and radio broadcasting of criminal trials. In 1962, a resolution of the Judicial Conference of the United States extended the coverage of Rule 53 to bar television from all federal courts and from the courtroom's environs. ${ }^{264}$ In addition, one member of the Estes Court was involved directly in another assessment of television's impact on society. Shortly before the Supreme Court agreed to hear Estes, Chief Justice Warren chaired a commission to investigate the assassination of President John F. Kennedy. ${ }^{265}$ The Warren Commission's report covered the impact of intensive press coverage on the sixth amendment rights of the accused assassin, Lee Harvey Oswald, and the influence of the press--particu-

259. See notes 100-02 supra and accompanying text.

260. See Kielbowicz, supra note 127, at 20-23. See also note 204 supra.

261. For a discussion of television as disseminator of news, see generally H. LAND Assocs., supra note 192; Hardin, The TV News Explosion, SATURDAY Review, Feb. 11, 1967, at 72.

262. See note 16 supra.

263. See note 257 supra.

264. FED. R. CRIM. P. 53 provides: "The taking of photographs in the court rooin during the progress of judicial proceedings or radio broadcasting of judicial proceedings from the court rooin shall not be pernnitted by the court." At its ineeting in 1962, the Judicial Conference of the United States, which is chaired by the Chief Justice, resolved to extend Rule 53 to cover telecasting, and to bar technological access to non-criminal proceedings and to the environs of the courtroon as well as to the court itself. [1962] JUD. CONF. ANN. REP. 9-10; Report of the Comm. on the Operation of the Jury System on the "Free Press-Fair Trial" Issue, 45 F.R.D. 391, 414-15 (1969); ABA Special Comın. on Proposed Revision of Judicial Canon 35, Interiin Report and Recommendations 95-100 (1962) (including correspondence with Chief Justice Warren on the resolutions passed by the Judicial Conference).

265. See President's Commission on the Assassination of President John F. KenNEDY, REPORT (1964). 
larly radio and television-on the events leading to his death. ${ }^{266}$ The shooting of Oswald by Jack Ruby presented additional prejudicial pubhicity problems because Ruby killed Oswald before an audience of millions who were riveted to their home television screens watching the aftermath of the President's tragic death.

Events like the killing of Oswald, coupled with television's coverage of other highly charged subjects such as the urban riots and the Vietnam war, fueled a suspicion that television by its nature created news rather than merely covered it. ${ }^{267}$ Subsequent years of experience have dulled the edge of suspicion about the socially subversive nature of television coverage; television has melted into American culture. As the Estes majority conceded could happen, society has become accustomed to television. ${ }^{268}$ For that reason alone, it may now be possible to expect the outcome in Chandler v. Florida ${ }^{269}$ to differ from that in Estes, and to reevaluate the ABA Canon.

\section{F. Are the Reasons to Limit Techological Access Persuasive?}

To the extent that Estes and Canon 3A(7) reflect fears about how television would cover trials, or concerns about the effects televised reporting might have on public attitudes and perceptions about the courts, they fail to weigl properly the interests at stake. To the extent that Estes and Canon 3A(7) attempt to control the size of the audience that will receive information about the courts, their aim is inconsistent with the first amendment. If anything, exposure of more people to more information about the operations of the courts would be a clear social benefit. Rationally considered, these bases for refusing technological access do not explain the rule more reasonably than does

266. Id. $196-242$.

267. See note 257 supra. On the Vietnam war, see also M. GREen, supra note 192, at 296:

The widespread American disenchantment with the long war in Vietnam, the swelling urge for peace, almost certainly derived in part from the fact that this was the first war since the Civil War in which the American civilian participated-by means of television. His participation was vicarious, but his emotional involvement was excruciatingly painful. It was the first war fought in everyone's living room.

On urban riots, see National Advisory Comm. ON Civil Disorders, Report 201-13 (1968), accusing the press of "overplaying" violence and of sensationalizing its riot coverage. The commission apparently considered television the most significant coverage because it found that "[t]elevision is the formal news source most relied on in the ghetto." Id. 207.

268. 381 U.S. at 551-52:

It is said that the ever-advancing techniques of public communication and the adjustment of the public to its presence may bring about a change in the effect of telecasting upon the fairness of criminal trials. But we are not dealing here with future developments .... [We] must take the facts as they are presented today.

Accord, id. at 595-96 (Harlan, J., concurring).

269. 366 So. 2d 64 (Fla. Dist. Ct. App. 1978), prob. juris. noted, 100 S. Ct. 1932 (1980). See notes 23-24 supra and accompanymg text. 
prejudice of lawyers and judges against the use of television in their domain.

No evidence exists to support the notion that recording equipinent, properly operated, inevitably violates the constitutional rights of criminal defendants or indeed affects thein differently from press coverage in general. Trial courts have the powers necessary to prevent disturbances $\mathrm{m}$ the courtroom. Problems of prejudicial pubhicity are not unique to cameras and recording equipment and can be managed by the same inethods used to prevent prejudice from other sources. Individuals involved in trials may experience substantial stress, but nothing suggests that technological access would increase the tension. Trial participants do not have enforceable privacy rights against the press and public. In any case, discrimmatory bans on cameras and recorders do not insulate trial participants from public and press scrutiny, but do impair substantial first amendment interests.

It is appropriate for courts to guard the interests of defendants zealously. But the courts should also be sensitive to the possibility that prejudice has madvertently tipped the rulemaking process toward an unsupportable demal of technological access. Judges and lawyers are accustomed to being removed froin intense pubhic scrutiny; ${ }_{2}^{270}$ in devising court rules and procedures like those at issue here, the legal profession may build into them its preference for inamtaining that distance. Because the same court frequently both inakes and reviews its own rules, ${ }^{271}$ it is easy for traditional preferences to survive challenges. To overcome the bias inherent in their own rules, courts inust make scrupulous efforts to be neutral. ${ }^{272}$ The current concern among the state courts reviewing their positions on technological access may portend the beginning of greater neutrality in this area of press and court relations.

\section{Permissible Limitations on Technological Access}

Although courts should not flatly ban technological access, they are not shorn of all powers to regulate that access. The courts may exercise their discretion to impose hinitations when necessary to pre-

270. Weinstein \& Zimmerman, supra note 109.

271. See, e.g., Hanna v. Plumer, 380 U.S. 460 (1964) (reviewing the statutory and constitutional validity of FED. R. Civ. P. 4(d)(1)); Mississippi Publishing Co. v. Murphree, 326 U.S. 438 (1946) (reviewing the validity of FED. R. Civ. P. 4(f)).

272. The difficulty faced by courts reviewing their own rules is discussed in Weinstein, Reform of Federal Court Rulemaking Procedures, 76 Colum. L. Rev. 905, 934-38 (1976). For expressions of concern about this issue by members of the United States Supreme Court, see 383 U.S. 1030, 1032 (1966) (amendments to FED. R. Civ. P.) (Black, J., dissentimg); 374 U.S. 865, 865-66 (1963) (ainendinents to FED. R. Civ. P.) (statement of Black and Douglas, JJ.). 
vent a clear danger to the right of fair trial, or when proper administration of the court justifies narrowly tailored restrictions on the time, place, and manner of technological access. Regulations to prevent unfairness will be needed ahnost exclusively at the trial level; appellate courts will rarely if ever face circumstances which justify more than time, place, and manner restrictions on the operations of newsgatherers.

\section{A. Technical Guidelines for the Use of Recording Equipment in the Courts.}

The presence of cameras in the courts makes necessary rules to protect the court against noise, disruption, and confusion. Regulation of the nuinber, placement, and noise level of cameras is necessary to enable the court to carry on its work free from interruption. 273 The accommodation of the due process rights of parties in civil and criminal proceedings also justifies these regulations.

While the press has asserted that it can voluntarily control the noise and distraction that accompany technological access, the facts in Estes suggest that court-1nade rules are a preferable way to avoid inadvertent interference with the trial, ${ }^{274}$ includimg accidental infringement of lawyer-client confidentiahty. ${ }^{275}$ Reasonable time, place, and manner regulations can establish the circumstances that require pooling between broadcasters, the sorts of equipment they may use, and the rules regarding placeinent of equipinent in the courtrooin.

The states vary inarkedly in low they approach the regulation of technological access. Florida, for example, formulated detailed statewide "standards of conduct and technology."276 After tests of still cameras before judges and press representatives, Florida prohibited models

273. See text accompanying notes 149-52 supra.

274. For example, at the pretrial hearing in Estes photographers wandered behind the bench to take pictures of the judge, 381 U.S. at 553 (Warren, C.J., concurring); a dozen cameramen were present with their equipment, $i d$. at 552-53 (Warren, C.J., concurring); and the placement of microphones created a risk that private bench conferences and consultations between defendant and counsel would be overheard. Id. at 536 (Warren, C.J., concurring). While the press may be able to avoid that kind of confusion by self-regulation on a case-by-case basis, the establishment of clear rules arrived at by a collaboration of press and court and applicable to all trials would help prevent errors of judgment and give all participants advance notice of what to expect.

275. The risk of interference with the lawyer-client confidentiality was present, at least at the pretrial stage, in Estes. Id. at 536. In Hudson v. State, 108 Ga. App. 192, 132 S.E.2d 508 (1963), a conviction was reversed because the placement of a radio microphone made it impossible for defendant to confer with counsel throughout the trial.

276. In re Post-Newsweek Stations, Fla., Inc., 347 So. 2d 404, 404 (Fla. 1977). The standards were adopted as permanent when Florida formally revised its Canon $3 \mathrm{~A}(7)$ in 1979. In re PostNewsweek Stations, Fla., Inc., 370 So. 2d 764, 782, 783-84 app. (Fla. 1979). 
noisy enough to disturb participants with their clicks and whirs, regulated details of placement of cameras and microphones, and adopted rules limiting the use of artificial lighting. ${ }^{277}$ Alabama, in contrast, left to each judicial circuit the task of coming up with reasonable regulations. The plan each circuit adopts is then subject to approval by the state supreme court. 278

However approached, the prior promulgation of rules of general applicability reduces the risk of interference with trial procedures. Prior promulgation of the rules saves the trial court from the need to make repeated rulings during the course of the trial-a problem which troubled the Supreme Court about the trial in Estes. 279 In addition, pre-existing rules, which can be challenged when promulgated, protect the press; if courts inake rules ad lioc at eacli trial, the press's only redress for unwarranted infringements would be an appeal-a remedy too late to permit effective coverage of the relevant trial. Generally applicable rules protect trial participants from insufficient restraints born of inexperience, and simultancously guard the press froin excessive restramts.

The rules should be formulated with substantial press participation, giving the press a chance to voice objections before the rules become final. One protection that should be built into any rulemaking process on this issue is a provision for periodic review of the guidelines, including review at the behest of the press. This safeguard avoids locking the courts and press into outmoded restrictions, and provides a ineans for correction of problens that develop when the rules are put into practice. Regulations that require the press and public to rely on devices such as pooling and to use only approved equipment restrict their freedom to gather news. As long as these rules are the least restrictive means to avoid physical interference with the trial, they are not unreasonable regulations and do not significantly injure first annendment values.

\section{B. Excessive Regulation that States Should Avoid.}

A court's inherent power to regulate the conduct of trials does not include the authority to impose restrictions on the news-gatherer's use of material once it has been obtained. One commentator has suggested that the courts should condition tcclinological access on a press agreement to cover trials regularly-not just when the broadcasters deein

277. See authorities cited in note 276 supra.

278. Alabama Canons of Judicial Ethics, Canon 3A(7A)(a) (effective Feb. 1, 1976), printed in ALA. CoDe. tit. 23, at 542 (Michie 1975).

279. 381 U.S. at 551. 
cases interesting 280 - and on a promise to "balance" coverage to treat the defendant and plaintiff or prosecution even-handedly. ${ }^{281}$ Some cases implicitly support these extreme notions. A concurring opinion in Estes, for example, suggests that a legitimate objection to television coverage is that tapes of the trial may be edited, or "commercialized" by association with advertisements. ${ }^{282}$ While the courts that recently have experimented with technological access have not imposed regulations on editorial discretion, they have, nevertheless, imposed other restrictions that are equally inconsistent with free speech. One rule, for example, conditioned the right to televise a trial upon an agreement that the videotape could not be used until all appeals in the case had been exhausted. ${ }^{283}$ This restriction on the televising of trials might be acceptable if the courts were inerely extending to the media a privilege which they could withdraw at will; it is unacceptable, however, when attached to a right of constitutional dimensions. Because the print press may report on the trial contemporaneously, and because broadcasters can discuss the case on the air as it proceeds, the theory proposed by this Article implies that the press has a right to print pictures and show videotaped scenes from the trial at its discretion. The gag order, a prior restraint, is no longer acceptable for limiting the freedom of the press to report its observations. ${ }^{284}$ No reason exists to justify the

280. See H. SKourNiA, supra note 257 , at 184-85. Skournia would also require stations to use reporters with legal training, to ban commercial sponsorship of court proceedings, and to agree, in return for a right to broadcast "live," that the entire trial will be aired. Id.

281. Id. 186.

282. 381 U.S. at 571 (Warren, C.J., concurring).

283. This limitation is imposed by the ABA's model Canon of Judicial Ethics $3 A(7)$ on the recordation of trials for educational purposes, see note 127 supra, which is still in effeet in about half the states. It was also imposed by the Eighth Judicial District Court of Nevada when it agreed to a preliminary test of broadcasting trials. Goldinan \& Larson, News Camera in the Courtroom During State v. Solorzano: End to the Estes Mandale?, 10 Sw. NEv. L. Rev. 2001, 2034 (1978). In the Nevada case, however, the limitation was imposed in part to avoid a violation of a state law that prohibited live broadcasts. The statute said nothing about videotapes shown after the trial. (The statute has since been amended to permit all broadcasting. 1979 Nev. Stats., Assembly Bill No. 571.) While these restrictions are questionable under American law, British law does permit orders barring press reports until completion of all proceedings by all media. The court's power is said, however, rarely to be invoked in this way. LIBRARY OF CONGRESS, MEDIA Coverage of Criminal Trials in Australia, Canada, and Great Britain at Gt. Brit. 4 (1975). A shightly different restriction was built into Wisconsin's new rule. That state prohibits use of film, videotape, photographic, or audio reproductions for "unrelated advertising purposes." Wisconsin Rules Governing Electronic Media and Still Photography Coverage of Judicial Proceedings, rule 12 (effective July 1, 1979), printed in 70 Wisc. 2d xix (1979). The provision provoked a dissent, refiecting concern about its constitutionality, from two inembers of the state supreme court. In re Code of Judicial Ethics, Wis., (filed June 21, 1979) (Abrahamson and Heffernan, JJ., dissenting in part).

284. Nebraska Press Ass'n v. Stuart, 427 U.S. 539 (1976). Nebraska Press does not explicitly preclude all uses of gag orders, but suggests that they could be used, if at all, only to prevent the most serious and inmediate threat of harm to a fair trial. 
use of this disfavored device to limit the choice of means by which information may be disseminated.

The vast majority of jurisdictions that permit technological access attach conditions upon the access, such as the requirement of prior approval by one or more participants in the action. ${ }^{285}$ Many states require both the judge and the criminal defendant or civil litigants to consent-often in writing-before electronic or photographic coverage will be permitted. ${ }^{286}$ Louisiana, in its pilot project, also required the consent of the district attorney and victin in a criminal action. ${ }^{287}$ The rules that require a defendant's prior consent in criminal cases have been drafted at least in part to accommodate Estes, which involved a nonconsenting defendant.

The argument for giving a criminal defendant the power to veto the presence of cameras at his trial is that it would accord maximuin protection to his interest in a fair proceeding. As the exercise of this veto would limit a first amendment right, however, it can be justified only if in the average case photography and broadcasting are prejudicial. As Part II of this Article argues, there is no empirical support for that proposition. The better rule, therefore, would be to require a defendant who objects to cameras to show that they would pose more than a speculative and insubstantial risk to due process in his case. ${ }^{288}$ Witnesses, parties, and jurors should not have an absolute veto either. As long as the trial is otherwise open, ${ }^{289}$ privacy concerns do not suffice to exclude cameras from the trial. ${ }^{290}$

285. See, e.g., Alabama Canon of Judicial Ethics $3 \mathrm{~A}(7 \mathrm{~A})(\mathrm{b}), 3 \mathrm{~A}(7 \mathrm{~A})(\mathrm{c})$ (effective Feb. 1 , 1976), printed in ALA. CoDE tit 23, at 542; Alaska Code of Judicial Conduct, Canon 3A(7)(c)(ii) (effective Nov. 1, 1979), In re Canon 3A(7), 5 Media L. Rep. 2494 (Alaska 1979); Georgia Code of Judicial Conduct, Canon 3A(8) (amended May 12, 1977), printed in 238 Ga. 855 (1977); Ohio Code of Judicial Conduct, Canon 3A(7) (effective June 1, 1979), printed in 58 Ohio St. xxxi (1979); Oklahoma Code of Judicial Conduct, Revised Canon 3A(7) (effective Jan. 1, 1979), printed in OKLA. Stats. ANN. ch. 1, app. 4 (West Supp. 1979); Tennessee Supreme Court Order, In re: Rule 43, Canon 3A(7)-Code of Judicial Conduct (amended Feb. 22, 1979), printed in TENN. CODE ANN. vol. 5a (Supp. 1979); Washington Code of Judicial Conduct, Canon 3A(7) (effective Sept. 20, 1976), printed in 87 Wash. 1119 (1976).

286. Such states include Alabama, Alaska, and Colorado (judge and criminal defendants only); Georgia (all parties); and Louisiana (all parties, including the district attorneys and victims of the crimes), see note 287 infra.

287. Louisiana Supreme Court Order Concerning Television and Court Rules and Regulations for Division B of the Ninth Judicial District Court for Rapides Parish (effective Feb. 23, 1978).

288. For an example of the circumstances in which a defendant might succeed in excluding cameras, see text accompanying notes $297-98$ infra.

289. See Richmond Newspapers, Inc. v. Virginia, 100 S. Ct. 2814 (1980).

290. As with defendants, special circuinstances may require that the court prevent technological access to protect witnesses and jurors. But such protection should be granted only upon a clear 
A requirement that individuals or representatives of the press notify the court prior to trial that some recording device will be used would not offend the right of technological access. Advance notice would permit courts to ensure that the equipment used, as well as the numbers of individuals required to operate it, would not physically interfere with the conduct of the trial. Advance notice would also permit the parties to the action to object and to present special problems to the court for resolution in advance of the actual trial.291

One final area to consider is whether the courts may limit the right of technological access to members of the institutional press. The Supreme Court lias thus far declined to identify any situation in which tlie Constitution treats the institutional press differently from individual citizens. ${ }^{292}$ If the press has a right under the Constitution to use cameras or recorders in court, the general public enjoys a corresponding right. In actuality, this expansive view of the rights of the public should not create insurmountable problems for the courts. Courts are not asked, or expected, to supply the equipment or the technical personnel needed to televise or broadcast proceedings; the news-gatherer bears the cost and responsibility of supplying appropriate cquipment. Thus, a higlı scliool civics class that wants to record a trial for school use ought to be able to do so if the board of education or the parents can supply the necessary tools. If both individuals and the organized press want to take pictures of or record a particular trial, rules on pooling could prevent a swarm of photographers and technicians from overwhehning the court; the individuals and the press may share the cost of producing the required coverage. Few individuals are likely to have the incentive or the wherewitlial to participate, but wlien they do, Supreme Court cases and sound policy both suggest that they should not be excluded.

\section{Limitations on Technological Access Because of a Compelling State Interest.}

The argument that reporters and the public should have a presumptive right to use cameras and recording equipment in court does

showing of need, and not merely because the individual requests it. See notes 293-98 infra and accompanying text.

291. Advance notice should probably not be required for the use of tape recorders, because these devices are not disruptive and are unlikely to create any other significant problems for anyone involved in a trial.

292. Houchins v. KQED, Inc., 438 U.S. 1, 11 (1978). See Blanchard, The Institutional Press and Its First Amendment Privileges, 1978 Sup. CT. Rev. 225. 
not mean that a judge can never exclude these devices. Occasionally it may be necessary to ban cameras during the appearance of particular witnesses or during the trial of certam defendants. But in order to do so some umque attribute of the equipment must cause a serious problem that more traditional forms of reporting do not. ${ }^{293}$ For example, the court may need to protect the safety of a witness-such as an individual who has received a new identity under the federal witness protection program. ${ }^{294}$ In certain cases, photographing witnesses would expose them to risks that would not be created if only their testimony were published.295 Those who know a witness by a new identity and who would not recognize him from reports using his former name might identify him from photographs or television newscasts. Similarly, undercover police agents involved in investigations may be recognized by a suspect who sees pictures of agents taken during a trial.296 These interests may suffice to deny all technological access during the time these witnesses are in the courtroom.

This exception, however, should not be applied unless it will actually accomplish its purpose. In most imstances, witnesses subject to the risk of recognition will not be sufficiently protected simply by banning television or still photography; publication of their names or other identifying facts, and the possibility of spectator recognition either inside or outside the courthouse, will still renrain as substantial threats. In these cases, the courts would continue their current practice of closing hearings while sucl1 witnesses are under examination.

A defendant's or witness's strenuous objections to the presence of cameras or electronic media raises a more difficult question: can a defendant's or a witness's subjective aversion to cameras require their exclusion? For example, a major exculpatory witness in a criminal case might refuse to testify before cameras. While criminal contempt is available, the choice of the witness to remain silent nray severely

293. Whenever a compelling reason is asserted to justify banning cameras or other devices, the court should not rule on the request until the press and public receive notice and are offered an opportunity to be heard.

294. Protected Facilities for Housing Government Witnesses Act of $1970 \S \S 501-504,18$ U.S.C. preceding $\$ 3481$ (1976).

295. In re Post-Newsweek Stations, Fla., Inc., 370 So. 2d 764, 778-79 (Fla. 1979) gives a detailed discussion of the kinds of problems whicl may require limited restrictions on technological access after a balancing of the conflicting interests at stake. See also Palm Beach Newspapers v. Florida, 378 So. 2d 862 (Fla. Dist. Ct. App. 1979) (witness safety asserted as a reason to bar photography, sketching, and television from court).

296. Cf. New York v. Jones, 47 N.Y.2d 409, 418 N.Y.S.2d 359, 391 N.E.2d 1335 (recognizing the court's power to protect undercover police agents, but finding that the power was improperly exercised in this case), cert. denied, 444 U.S. 946 (1979). 
prejudice the defendant's sixth amendment rights. When the ability to proceed with a fair trial is thrown into doubt, it inay be preferable to exclude recording equipinent from that seginent of the trial. Similarly, a defendant who claims he will be too distressed by the presence of cameras to participate in his own defense may have a valid argument for keeping thein out of his trial.

A variant of this problem occurred in Florida. A defendant in a grand larceny case coinplained that in the hight of her recent psychotic depression, television caineras in court would so disturb her that she would be incoinpetent to stand trial.297 In this case, television itself could not be said, objectively, to create any unusual risk to the defendant; at issue was the camera's effect on her subjective perceptions. The Florida District Court of Appeals concluded that the incompetency claim warranted an evidentiary hearing. ${ }^{298}$ Though courts must respond flexibly to the unusual case in order to safeguard due process rights, too inany exceptions like these could quickly devour the proposed right of technological access.

Courts should be particularly wary of extending the "subjective aversion" exception to exclude cameras from otherwise public trials for the purpose of protecting the complaining witness in a sex crime case. ${ }^{299}$ Courts have einployed various techniques in the past to defend these witnesses: in some states, statutes or the courts' inherent powers permit exclusion of all the press and public froin particularly sensitive cases or testimony. The rationale behind this rule is that the requireinent of testifyimg publicly will inhibit or psychologically scar certaim witnesses. ${ }^{300}$

Closing the court is not an ideal way to protect witnesses in sexual assault cases. Exclusion is an extreme response that interferes with the

297. Green v. State, 377 So. 2 d 193 (Fla. Dist. Ct. App. 1979).

298. Id. at 201.

299. New Jersey's experimental guidelines for broadcasting trials specifically exclude juvenile court cases, rape cases, child custody and divorce proceedings, and trials involving trade secrets. New Jersey Supreme Court Order (Mar. 15, 1979). Florida, which has one of the broadest rules, establishing a presumption in favor of teclinological access, nevertheless recognizes the need to protect children in custody battles, sexual battery victims, and others in comparable situations from exposure to cameras and recording equipment. In re Post-Newsweek Stations, Fla., Inc., 370 So. 2d 764, 779 (Fla. 1979). But $c f$. New-Press Publishing Co. v. Shearer, 5 Mcdia L. Rep. 1272 (Fla. Dist. Ct. App. 1979) (setting aside an order barring a reporter from court during the testimony of a juvenile in a sex-crime trial).

300. See, e.g., N.Y. JudiciarY Law \& 4 (McKinney 1968); New York v. Jones, 47 N.Y.2d 409, 418 N.Y.S.2d 359, 391 N.E.2d 1335, cert. denied, 444 U.S. 946 (1979) (discussing the trial court's discretion to exclude the public from the testinony of a particular witnesses). See generally Note, Exclusion of Public from a Proceeding Merely Upon Request is in Exeess of Court's Power, $30 \mathrm{U}$. MIAMI L. REV. 1075 (1976) (discussing the linits of judicial discretion in barring the public and press from a marriage proceeding). See also note 229 sipra. 
public's interest in the open administration of justice; 301 it also may run counter to the defendant's interest in a public trial. ${ }^{302}$ Certainly, if the recognition of a right of technological access encourages judges to close courtrooms inore frequently, either during the testimony of the rape victim or for the whole trial, it will foster neither public justice nor the free exchange of ideas.

The focus on a choice between barring media technology or closing the courtroom clouds the issue, because neither device really addresses the major problems such witnesses face. Complainants in sexual assault cases traditionally have needed protection from publicity largely because they risked, when they took the stand, impeachment through an often brutal examination of their prior sexual histories. Modern rules of evidence that limit the scope and nature of the pernissible inquiry respond directly to humiliation of witnesses; rules that regulate the composition of the audience do not. ${ }^{303}$ Furthernore, rape shield laws cure without incurring a cost to the intercst in public trials.

In those jurisdictions that routinely try sexual assault cases im open court, even with the protection of strict evidentiary rules the witness will probably continue to find that the compulsion to testify publicly to the events of the assault will engender soine additional psychic pain. That does not inean she can exclude the public, because participants in trials do not have a clear legal claim to be free from public scrutiny. Privacy claims should not, therefore, suffice to bar the electronic and photographic press unless the state can demonstrate some difference in harin, uniquely attributable to the presence of cameras or microphones, that justifies the exclusion of cameras and recorders alone. Appearing before an audience composed of jurors, spectators, print reporters, court artists, and the defendant is stressful in itself; the witness's anguish is unlikely to be fundamentally changed by the expanded range of unseen spectators. Unless the electronic and pliotographic press can be shown to create problems that are not caused by other reporters, discriminatory treatment cannot be justified.

301. Richmond Newspapers, Inc. v. Virginia, 100 S. Ct. 2814, 2823-25 (1980); Lexington Herald Leader v. Tackett, 49 U.S.L.W. 2041 (Ky. June 24, 1980); New York v. Jones, 47 N.Y. 2d 409, 418 N.Y.S. $2 d$ 359, 391 N.E. 2d 1335, cert. denied, 444 U.S. 946 (1979); State ex rel. Oregonian Publishing Co. v. Deiz, 613 P.2d 23 (Or. 1980).

302. The defendant's right to a public trial is set out in U.S. Consr. amend. V1.

303. A typical evidentiary rule limiting the inquiry which may be made into the sexual beliavior of an alleged victim of rape or sexual assault is FED. R. EvID. 412, which was approved by Cougress in 1978. Pub. L. No. 95-540, § 2(a), 92 Stat. 2046 (1978) (codified at 28 U.S.C.A.). See also N.Y. CRIM. Proc. LAw $\$ 60.42$ (McKinney Supp. 1979) for a similar provision. At tlie time the federal rule was approved, some 30 states liad revised their rules to protect sexual battery victims from umrecessary intrusive questioning. 124 CoNG. REC. H11,945 (1978) (remarks of Rep. Holtzman). 


\section{Conclusion}

This Article proposes a modest alteration in the existing view of the first ainendment. News-gathering by the tcchnological methods appropriate to each medium of communication should be recognized as entitled to constitutional protection. This expansion in the scope of the first amendment is necessary to ensure that news media may convey information without interference for capricious or insubstantial reasons.

When the technical methods of information gathering are restricted, the content of the communication is inevitably and importantly affected. In a jurisprudence that attaches special importance to news-gathermg, communication about public officials, and exposure of the operations of government, restrictions on technological access to the events and actors are especially serious limitations on the free exchange of idcas. Nevertheless, such restrictions have been imposed routinely with only the barest examination of the resulting impairment of the freedom of speech and press, and with scarcely more thought to the reality-much less the weight-of the interests that are thereby preferred.

A constitutional right of technological access would require that the government impose no nore restrictions on the means by which its performance is reported than are strictly necessary to accommodate the countervailing constitutional requirements of orderly process. Recogmition of this right, and of its place in the courtroom, will promote a greater public understanding of the work of the judiciary witlout imposing any measurable costs. Despite the controversy that has surrounded technological access for over half a century, an examination of the issue suggests that a recommendation for constitutional protection of that aspect of news-gathering is actually a very modest proposal. 